\title{
Érzelmi regulációs változások krízisben és traumában - a helyreállítást segítő, pszichológiai tanácsadás során alkalmazható módszerek és gyakorlatok
}

\author{
MOGYORÓSY-RÉVÉSZ ZSUZSANNA \\ Metamorfózis Múhely, Budapest \\ ELTE Eötvös Loránd Tudományegyetem Pedagógiai és Pszichológiai Kar \\ Pszichológiai Intézet, Budapest
}

(Beérkezett: 2018. március 4.; elfogadva: 2019. január 5.)

\begin{abstract}
A tanulmány a szelfreguláció egyik alapvető folyamatát, az érzelemszabályozást helyezi fókuszába. Az emócióreguláció néhány elméletének és idegrendszeri alapmechanizmusának áttekintése után az akut és krónikus stresszhatások és az azokra adott adaptív szervezeti válaszok bemutatása következik, kiemelt szempontként az arousalfolyamatokban bekövetkező változásokra. Bár fontos vonatkozás, de jelen tanulmányban csak vázlatszerúen kerül bemutatásra a tartósan fennálló stresszhatásra bekövetkező aktivációsszintmódosulások kapcsolata a kötődési jellemzőkkel, illetve a későbbi pszichopatológiával. A cikk legfontosabb célja az érzelemregulációban szerepet játszó idegrendszeri háttérmechanizmusokra alapozva olyan - a pszichológiai tanácsadás során is alkalmazható technikák és gyakorlatok áttekintése, illetve rendszerezése, amelyek a szabályozás helyreállításában támogathatják a személyt. A bemutatás az arousalkontinuumban észlelt változások alapján létrehozott csoportosítást (hiper-, illetve hipoarousal tartomány) követve nyújt betekintést abba, hogy hogyan segíthetjük hozzá klienseinket egy adekvátabb stresszkezelési, érzelemszabályozási stratégia, szokásrendszer kialakításához, egy személyre szabott ún. „öngondoskodási terv” kialakításához. Az érzelemszabályozást támogató „tanácsadási fókusz" kiindulópontjaként a stresszkezelési stratégiák felmérése szolgál, amit egy edukációs és „,tréning” folyamat követ, amely során a kliens elsajátíthatja és szokássá alakíthatja az aktuális állapotához leginkább illeszkedő érzelemszabályozási technikákat, gyakorlatokat. A munka hatákonyságának illusztrálását a gyakorlati tapasztalatok felvázolásán túl két esetvignetta is szemlélteti.
\end{abstract}

Kulcsszavak: érzelemreguláció, arousal állapotok, hiperaktiváció, hipoaktiváció, stressz, krízis, érzelemregulációs gyakorlatok

\footnotetext{
* Levelezési cím: dr. Mogyorósy-Révész Zsuzsanna, Metamorfózis Múhely, 1163 Budapest, Fuvallat utca 37.b. E-mail: mogyorosy.revesz.zsuzsa@gmail.com
} 


\section{Kontrollszükséglet, önszabályozás, érzelmi reguláció}

Az önmagunk és a környezetünk feletti kontrollérzésre való törekvés alapvető emberi szükséglet, az önmeghatározás egyik aspektusa (Rossouw, 2014). Ugyanakkor maga a kontrollérzés, azáltal, hogy lehetőséget teremt egy adott helyzetben várható kimenetel felbecslésére, képes csökkenteni a distressz állapotot (Dahlitz, 2015). Ez utóbbi szempont vezérelte ennek az írásnak a létrejöttét. A stresszcsökkentésben alkalmazott ún. jó gyakorlatok (technikák) szakirodalmi hátterú rendszerezését és alkalmazási lehetőségeit igyekeztem áttekinthetôvé tenni a gyakorlati munka, speciálisan a pszichológiai tanácsadás számára, ahol a krízisintervenció és ezzel kapcsolatban az emócióregulációs folyamatok ismerete alapvető fontosságú.

Az önszabályozás, mint az önmagunk feletti kontroll, a személyiség, a szelf egyik központi funkciója, olyan többkomponensú, hierarchikus szerveződésú folyamatok összességét jelenti, amelyek képessé tesznek valakit arra, hogy rövid és hosszú távú célokat túzzön ki és ezek elérésének érdekében kontrollálja gondolkodását, érzelmeit, cselekedeteit, azaz szervezetten viselkedjen (Maccoby, 1980). Szúkebb értelemben az önszabályozás akaratlagos funkció, tágabb értelemben beletartoznak automatikus, tudattalanul zajló fiziológiai folyamatok is, mint amilyen az arousal és egyéb fiziológiai változók szabályozása (szívfrekvencia, vérnyomás, glükózszint stb.). Az automatikus önszabályozás Rosenbaum (1988) modellje szerint túlnyomórészt tudattalanul zajló fiziológiai folyamatokat jelent, míg a szelfkontroll tudatos és kognitív vezérlésú.

Az önszabályozás egyik fontos komponense az érzelmek szabályozása, ami azt jelenti, hogy az aktuálisan keletkező érzelmeinket mennyire vagyunk képesek befolyásolni, milyen mértékben tudjuk kontrollálni kifejezésüket. Ez nemcsak a negatív érzelmek csillapítását, vagy kinyilvánításának gátlását, hanem a pozitív érzelmek fenntartását, növelését is jelentheti, azaz alapvetően az érzelmi arousal fenntartását, fokozását, illetve különböző mértékú gátlását egyaránt magában foglalja (Bóna, Kun, Kökönyei, \& Demetrovics, 2013; Thompson, 1994). Az érzelemszabályozási zavarok számos pszichopatológiai állapotban szerepet játszanak, de nem tekinthetók specifikusnak adott zavarra; a szakirodalom transzdiagnosztikus rizikótényezőknek tartja őket és hangsúlyozza terápiás relevanciájukat, kezelésük fontosságát (Bóna és mtsai, 2013).

Az érzelemszabályozásnak vannak tudattalanul, automatikusan lezajló, ún. implicit és kognitív vezérlésű, tudatos kontrollfolyamatokra épülő, explicit összetevői (Greenberg, 2008). A szerző értelmezésében implicit vagy automatikus érzelemszabályozási folyamatoknak tekinthetők például az önmegnyugtató viselkedések, a distressz állapot kommunikációja (pl. 
vokalizációval), a társak keresése, a szemkontaktus felvétele. Ezek a „stratégiák" alapvetóen jobb féltekei folyamatokon alapulnak és a korai kapcsolatok tapasztalatai alapján szerveződnek. Az érzelmi szabályozás explicit öszszetevői nagymértékben függnek olyan kognitív képességektől, mint a végrehajtó funkciók eredményessége, a tudatos erőfeszítés a kontrollra és a figyelmi múködés. Ezek a folyamatok segíthetik az egyént az önkontroll, a szabályozottságérzés megtartásában és visszanyerésében (Fox \& Calkins, 2003; idézi: Harmatiné \& Pataky, 2014), nagyrészt a bal féltekei funkciókkal állnak kapcsolatban. A tudatos, erőfeszítést igénylő (explicit) és a tudattalan vagy automatikus (implicit) érzelemszabályozási folyamatok valójában egy kontinuumot alkotnak, azaz nem érdemes „vagy-vagy” alapon elkülöníteni ezeket (Gross, 1998).

Az érzelemszabályozás folyamatmodellje szerint (Gross \& John, 2003) az emóciószabályozási stratégiák aszerint is megkülönböztethetők, hogy az érzelmek megjelenésének, kifejeződésének folyamata során mikor lépnek be a regulációs múködések. Ennek alapján megkülönböztethető az ún. előzmény- és válaszfókuszú stratégia. Gross és John (2003) vizsgálatai alapján az előbbinek tipikus példája a helyzet kognitív újraértékelése (Lazarus \& Alfert, 1964), ami pozitív kapcsolatban áll a szubjektív jólléttel, míg a válaszfókuszú stratégiák - mint például az érzelmek elnyomása -, negatív kapcsolatot mutatnak a jóllét állapotával.

Az érzelemszabályozás stratégiáinak, mintázatának kialakulásában az örökletes faktorok (Goldsmith, Pollak, \& Davidson, 2008), mint a temperamentum (Rothbart \& Putnam, 2002) vagy a regulációs kapacitás (Bauer \& Baumeister, 2011), és a környezeti tényezők egyaránt szerepet játszanak. Ez utóbbiak közül elsősorban az anyai válaszkészségnek, érzékenységnek (Spinrad és mtsai, 2007), melegségnek, támogatásnak (Eiden, Edwards, \& Leonard, 2007) és az elsődleges kötődés minőségének, típusának (Láng, 2009) van kiemelkedő szerepe. A biztonságos kötődés megalapozza a jól múködő érzelmi szabályozást, stresszkezelést, a pszichés egészséget, a társas kapcsolatok megfelelő funkcionálását, míg a korai ártalmas tapasztalatok ellenkező hatásúak (Perry, 2009; 2014). A bizonytalan és ezen belül különösen a dezorganizált kötődés számos későbbi pszichés probléma rizikótényezője (Kuritárné, 2015). A kötődés és a későbbi pszichés zavarok közötti egyik lehetséges összekötő mechanizmus éppen az affektív szabályozás. Az arousalállapotok sikeres szabályozása és a kötődés összefüggését Crittenden (2000) is hangsúlyozta. A korai életkorban kialakuló érzelemregulációs deficitek az affektív szabályozás tartós funkcióromlásához vezethetnek (Eisenberg, Spinrad, \& Eggum, 2010). Ugyanakkor az emóciókontroll képessége az élet folyamán változhat, Gross és munkatársai (1997) azt találták, hogy az életkor előrehaladtával növekedhet. 


\section{Stressz, krízis, trauma, adaptív szervezeti válaszok és az érzelemszabályozás zavarai}

\subsection{Alapfogalmak}

A szakirodalomban a stressz, krízis, trauma, negatív életesemény, kritikus esemény jelentésének és összefüggéseinek tisztázása a fogalmi félreértések sorát rejti magában. Jó áttekintés olvasható erről Csürke, Vörös, Osváth és Árkovits (2014) munkájában. Jelen tanulmány, illetve a pszichológiai tanácsadás szempontjából a krízis a kiinduló fogalom, mivel ennek kezelése tanácsadói kompetencia. A krízisállapot természetesen összefügg a stressz kérdéskörével és a krízisintervenció Roberts-féle modelljének szemléletében kapcsolódik a traumatizáció, traumakezelés témaköréhez is (Roberts, 2002).

A krízisállapot nem pszichodiagnosztikai kategória, hanem egyrészt természetes velejárója a személyiségfejlődésnek, mint fejlődési krízis (Erikson, 1991), másrészt lehet akcidentális, eseti történés (Holmes \& Rahe, 1967). A krízis olyan, lélektanilag kritikus állapotot jelent, amely a veszteség, fenyegetettség elóvételezését, a kilátástalanság és elveszettség érzetét okozza. A személy nem képes elkerülni a fenyegető helyzetet, viszont megküzdési módjai nem elegendőek a helyzet megoldásához (Caplan, 1964). A krízisfolyamat pár hét alatt lezajlik (Hirschowitz, 1967), egyaránt magában hordozza a pozitív kimenetel, megújulás valamint a negatív irányú változás lehetóségét is (Balikó, 1990). A krízisintervenció minimális célja a válsághelyzet kezelése és a korábbi egyensúlyi állapot visszaállítása, maximális célja egy fejlettebb egyensúlyi állapot elérése, a válsághelyzet kreatív krízissé alakítása (Telkes, 1989).

Az, hogy a krízist kiváltó negatív életesemény traumatikus hatásúvá válik-e, függ a személyiségfejlődés szakaszától, az adott nehézséggel kapcsolatos korábbi tapasztalatoktól, az aktuális pszichés állapottól és a társas támogatás mértékétól (Bakó, 1996). Itt érdemes tisztázni, hogy maga a trauma fogalma olyan állapotot jelöl, amely váratlan, heveny jellegú, pszichés dezorganizáltsághoz vezetó, azonnali emocionális sokkal járó esemény következtében alakul ki (Bakó, 1992), míg a traumatizáció kifejezést olyan folyamatoknál alkalmazzuk, amikor a traumatikus hatás lassabban jelenik meg, és az ártalmas ingerek mintegy kumulatív módon fejtenek ki károsító hatást (Van der Kolk, 2011).

A szervezet az ôt érő káros ingerekre (stresszorok) a hatás nagyságától és idejétől függően alarm-reakcióval reagál, amely az agyi események természetes neurokémiai kaszkádját jelenti, célja a homeosztázis helyreállítása (Andrejkovics, 2015). Beindul a Cannon-féle vészreakció, amely felkészíti a szervezetet a megküzdésre vagy a menekülésre, a vegetatív idegrendszer szimpatikus részének gyors aktiválódása révén (a Symphatetic-AdrenoMedullary System aktivációja). Stresszhatásra azonban emellett a HPA- 
tengely (hipotalamusz-hipofízis-mellékvesekéreg) is aktiválódik, ami egy lassabb, de tartósabb hatású választ indukál. Ha a stresszor túl hosszan hat, és a szervezet alarm-reakciója nem vezet eredményre, illetve ha a stresszor ismétlődően jelentkezik, akkor a szervezet az általános adaptációs szindrómával (GAS) reagál (Selye, 1964). A természetes neurokémiai kaszkád elhúzódik, a homeosztázis regulációja felborul, amely hatással van az agy szerkezeti és múködési jellemzőire egyaránt (Heim és mtsai, 2000; Wilson és mtsai, 2011), illetve végső esetben a szervezet kimerüléséhez, pusztulásához vezet. Az arousalkontinuum változásaival összefüggésben kognitív, emocionális és viselkedéses változások regisztrálhatók (Perry, 2004). A tartós és/vagy gyakran ismétlődő stresszhatás, azaz a krónikus traumatizáció (Van der Kolk, 2011) egyik hosszú távú következménye, hogy a traumatizált személy tolerancia-ablaka (Siegel, 1999), azaz az ingerek kiváltotta emóciók kezelésének, az információk produktív feldolgozásának képessége jelentősen szúkül (Ogden, Pain, \& Fischer, 2006).

\subsection{Válaszmintázatok}

a stresszre és az érzelemszabályozás zavarai

A stresszre adott válaszmintázatnak két típusa különíthető el az arousalkontinuum mentén: az egyik a hiperarousal kontinuum részeként, a "fight or flight”, azaz a „küzdj vagy menekülj” reakciók (mint amilyen pl. egy esetleges támadóval való szembeszállás vagy segélykérés a környezettől); a másik típus a hipoarousal vagy disszociatív kontinuum mentén írható le (ledermedés [freezing] és egyéb disszociatív reakciók, mint pl. a leblokkolás vagy a derealizáció, deperszonalizáció). Ezek a mintázatok valamilyen mértékben függenek az életkortól, a nemtől és a stresszhelyzet körülményeitől (ld. 1. ábra, Perry, 2004, alapján).

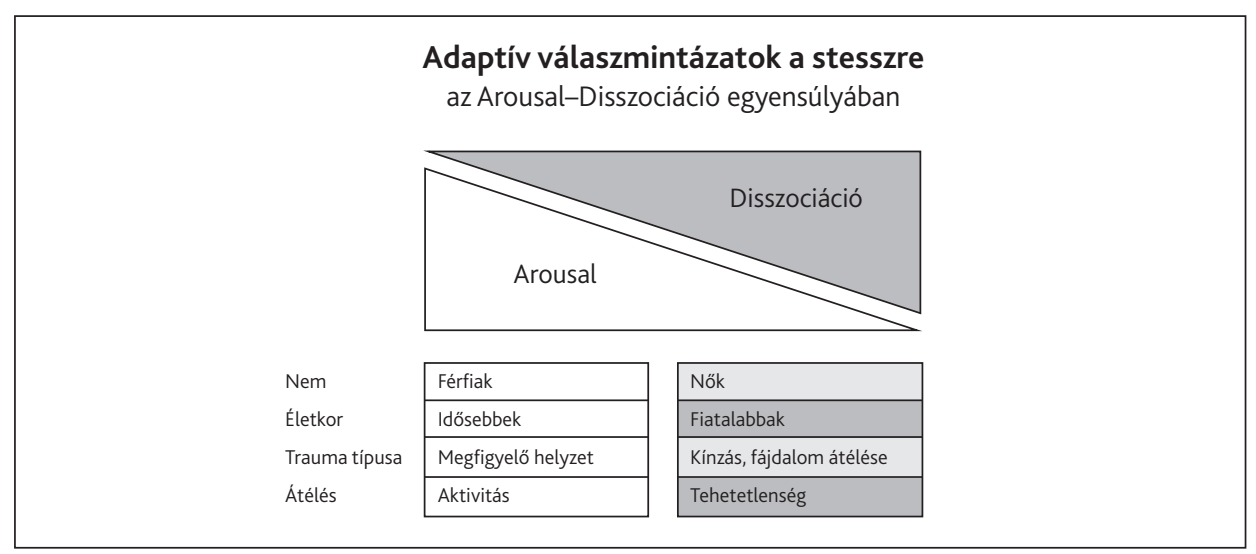

1. ábra. Adaptív válaszmintázatok a stresszre (Perry, 2004) 
Általánosságban elmondható, hogy fiatalabb gyermekekre, nókre, kínzás elszenvedóire, a tehetetlenséget megélókre a disszociatív mintázat jellemzőbb, míg felnőtt férfiak, megfigyelő helyzetben lévők (szemben az átélőkkel), illetve valamilyen aktivitás kifejtésére való képesség esetében inkább hiperaktivációs reakciósorozat várható (Perry, 2004).

A kezdetben adaptív stresszválaszok tartós fennállása (elhúzódó krízis, traumatizáció hatására) érzelemszabályozási anomáliákhoz vezet. Ezek alapvetően két formában nyilvánulhatnak meg: kialakulhat egy ún. hiperaktivációs stratégia, amit a negatív érzelmek és az ezek által átszínezett percepció túlsúlya jellemez. Az érzelemregulációs zavarok másik nagy csoportját deaktivációs (hipoaktivációs) vagy a traumatizációval kapcsolatos elméleti megközelítésben disszociatív típusnak nevezzük (Lanius és mtsai, 2010; Perry, 2004), amit a negatív és pozitív érzelmek távoltartásának tendenciája jellemez.

Előfordul, hogy a hiperarousal és a disszociatív állapotok viszonylag gyors egymásutánban váltakoznak. Ez jellemző lehet krízisállapotban, akut stressz-zavarban, de poszttraumás stresszbetegség (PTSD) esetében is. A gyors oszcilláció a hiper- és hipoarousal állapotok között az idegrendszer „kétségbeesett" kísérlete a reguláció helyreállítására, ún. „bifázisos hullámvasút" (Corrigan, Fisher, \& Nutt, 2011), amely egyrészt egy adaptív múködés, hiszen mindkét fázis a túlélést szolgálja, másrészről azonban a folyamatos váltakozás, illetve a két szélsőséges állapot ismétlődő megjelenése maladaptív hatású. Emögött az a mechanizmus áll, hogy ha az észlelt fenyegetettség (fájdalom, rettegés, kiszolgáltatottság, stb.) elviselhetetlen mértékúvé válik, akkor a disszociatív kontinuum múködése kapcsol be (lefagyás, érzéketlenség, ájulás, stb.). Ahogy csökken az észlelt fenyegetettség mértéke, újra a hiperarousal aktivitás lép múködésbe, újabb esélyt adva a szervezetnek a megküzdésre (Perry, 2004).

Az érzelemszabályozás zavarai lehetnek átmenetiek, pl. krízisállapotban, akut stressz zavarban, amikor a szervezetet éró károsító inger (stresszor) túl intenzív, és/vagy váratlan. Ilyen esetben a regulációs zavar a krízis, illetve akut stresszállapot elmúltával néhány héten belül rendeződhet, a szervezeti múködések helyreállnak. Ha a stresszorral való megküzdés sikertelen, traumatizált állapot jöhet létre (PTSD, krónikus traumatizáció, vagy alkalmazkodási zavar a stresszhatás idejétől függóen; DSM-5, 2014). A kezdetben adaptív stresszreakciók tartós fennállása - összhangban a Selye-féle általános adaptációs szindrómában leírtakkal - poszttraumás tüneteket okozva, a szervezetet károsító hatásúvá válik.

Az akut stresszhelyzetben múködő predomináns adaptációs válaszmintázat előrevetíti, hogy poszttraumás állapotban (PTSD) milyen típusú tünetek várhatók: hiperarousal vagy inkább disszociatív jellegúek. Krónikus 
traumatizációnál a traumatizáción alapuló későbbi diagnózis szintén összefüggésbe hozható az érzelemszabályozás sajátosságaival (Del Río-Casanova, González, Páramo, Van Dijke, \& Brenlla, 2016).

\subsection{Az érzelemszabályozási zavarok kapcsolata a kötődéssel}

Mint fentebb említésre került, a kötődési típusok és a későbbi pszichés zavarok, valamint az affektív szabályozás kapcsolatban állnak egymással. Crittenden (2000) információfeldolgozási modelljében a különböző kötődési típusok a különböző gondozói környezethez való alkalmazkodás információfeldolgozási és affektív szabályozási stratégiáit jelentik. Kiegyensúlyozott, integrált információfeldolgozásra a biztonságos kötődés teremt alapot. Elkerülő kötődés esetében a testből származó viszcerális információk, míg ambivalens kötődésnél a környezeti, kontingencián alapuló információk feldolgozása kap kevesebb figyelmet. Dezorganizált kötődésnél nincs szervezetten, következetesen múködő információfeldolgozási stratégia. Ezek az eltérő információfeldolgozási módozatok az elkerülő személyek esetében túlszabályozáshoz (deaktiváció), az ambivalens kötődésúnél alulszabályozáshoz (hiperaktiváció), míg a dezorganizált kötődésúnél szabályozatlansághoz vezetnek (Láng \& Nagy, 2013).

Az arousaljellemzőkön túl a keletkező pszichés problémák megnyilvánulhatnak internalizációs és externalizációs zavarok formájában (Eisenberg és mtsai, 2010). Az internalizációs jelleg a szorongások számos fajtájában, hangulati és egyéb zavarokban jelenik meg (pl. depresszió, visszahúzódás, aggodalom, szomatikus panaszok), az externalizációs problémák pedig a környezet számára sok esetben zavaró magatartási problémákban fejeződnek ki leginkább (pl. agresszió, dac, normasértő viselkedés). Mindkét állapotra jellemző a negatív érzések csillapításának nehézsége, de a zavaró érzelmek és viselkedések egyik esetben a külvilág felé (externalizáció), másik esetben elsősorban „befelé” (internalizáció) manifesztálódnak (Macklem, 2008).

A fejlódési pszichopatológia - a maladaptív viselkedésmintázatok kialakulásának felderítésével foglalkozó irányzat - egyik elméleti megközelítésében az anyai gondozás és a kötődés összefüggéseit vizsgálva azt találták, hogy az anyai depresszió a fejlődés későbbi szakaszában inkább internalizáló patológiát (Cicchetti, Rogosh, \& Toth, 1998), míg a bántalmazás inkább externalizáló zavarokat eredményez, főként fiúknál (Yates, Dodds, Sroufe,\& Egeland, 2003). Láng és Nagy (2013) tanulmányukban említik, hogy a kötődési minőség és a patológiás állapotok, illetve ezek hiányának összefüggéseiről készült vizsgálatok során azt találták, hogy a biztonságos 
és dezorganizált kötődés jóval erősebb hatással van az egyén későbbi sorsára nézve, mint az elkerülő és ambivalens kötődés. Ez utóbbiakat tekintve is vannak azonban olyan eredmények, miszerint az elkerülő kötődés és a későbbi antiszociális viselkedés és externalizáló problémák; valamint az ambivalens kötődés és a társas visszahúzódás, szorongásos zavarok között kimutatható az összefüggés.

\section{Idegrendszeri háttérmechanizmusok}

A következókben a teljesség igénye nélkül, az érzelmi regulációban kiemelkedően fontos idegrendszeri struktúrák és múködések vázlatos áttekintése következik.

\subsection{Kortiko-limbikus kapcsolatok}

A mögöttes idegrendszeri mechanizmusok lényegében a kortiko-limbikus gátláson alapulnak (Lanius és mtsai, 2010). Az aktiváció (arousal) szabályozását sokszoros idegrendszeri kapcsolódás teszi lehetővé. Egyrészt „,alulrólfölfelé": a vegetatív idegrendszer és az agy kéreg alatti régiói (agytörzs, hipotalamusz, inzula, amygdala) felól az agykéreg felé, másrészt „felülrőllefelé": a kéregtől (prefrontális régiók közül a ventromediális, laterális, valamint az anterior cinguláris kéreg) az alsóbb régiók irányába.

Amennyiben a prefrontális kéregterületek gátló múködése alacsony szintú és a kéreg alatti, limbikus múködések dominálnak, az érzelmek alulszabályozásáról beszélünk. Ilyenkor az érzékleti élmények, emóciók kontrollálhatatlanul elárasztják a személyt, az ún. fenyegetésdetekciós rendszer túlreagál, és hiperaktivációs tünetek jelennek meg.

Fordított esetben, amikor a prefrontális területek intenzív gátlást fejtenek ki az alsóbb agyi régiókra, az érzelmek túlszabályozása áll elő, azaz az érzelmekkel, érzékletekkel való kapcsolat átmenetileg deaktiválódik, disszociálódik, és hipoaktivációs vagy deaktivációs tünetek megjelenése várható. Traumatizáló helyzetekben az emóciók általi extrém mértékú elárasztottság esetében a prefrontális régiók múködése "szétkapcsolja” az információfeldolgozást, az érzelmek átélése ármenetileg gátlódik, a memóriamúködés megváltozik, az élmény részekre szakad (Lanius és mtsai, 2010).

\subsection{Agytörzsi szabályozó rendszer}

A reguláció áttekintésekor fontos megemlíteni a hiper-, illetve hipoaktiváció létrehozásában szintén szerepet játszó nervus vagushoz kapcsolódó agytör- 
zsi szabályozó rendszert, amelynek első szintje az agytörzsi magvak és szív közötti vegetatív kapcsolatot, második szintje pedig az agytörzs és a kéreg közötti kétirányú kommunikációt jelenti. Porges (2009) polivagális elmélete a szociális viselkedés szabályozását egyrészt a vegetatív regulációval, elsősorban a szívmúködés vagális kontrolljával, másrészt a fizikai és a társas környezet biztonságának nem tudatos értékelésével (neurocepció) hozza összefüggésbe (S. Nagy, 2009). A kéreg szerepe, hogy felmérje, értékelje a környezet biztonságosságát, majd ennek megfelelő fiziológiai állapotot és viselkedést indukáljon a vagális fék szabályozásának útján. Porges (2009) érvelése szerint a biztonságos környezet magas vagális tónussal, alacsony szívritmussal, az anyagcsere felgyorsulásával hoz létre olyan fiziológiai állapotot, amely segíti a pihenést, az önnyugtatást és a szervezet újraépülését, illetve a kapcsolódást, szociális kötelékteremtést. Ez az aktiváció a ventrovagális komplexumhoz köthető. Ha a neurocepció (a környezeti kockázat automatikus felmérése) úgy ítéli meg, hogy veszély áll fenn, kétféle válaszlehetőség felé nyílik út. Az alacsony vagális tónussal, szimpatikus aktivitással, fokozott szívritmussal és lelassult anyagcserével a „harcolj vagy menekülj" viselkedést indukálva az élőlény védekezését mobilizálja, és ha ez az aktív stratégia eredménytelen, akkor passzív választ, a vérnyomás és a szívritmus csökkenésével együttjáró immobilitást (hipoaktív, disszociatív állapotot) indukál a dorzális vagális komplexum aktiválódásával, és egyúttal opioid-mediált analgéziával (Porges, 2007; idézi: S. Nagy, 2009).

\subsection{A neurotranszmitterek szerepe}

Az opiátok mediálta analgézia (a fájdalomérzés csökkenése, hiánya) - amit a fenyegetés hatására a középagy periakveduktális szürkeállománya (PAG) dorzolaterális és laterális oszlopai aktiválnak - kontrollálhatatlannak ítélt helyzetekben jelentkezik, és együtt jár a tehetetlenség, reménytelenség átélésével, ami nagy valószínúséggel PTSD-hez vezethet, ha a kontroll és / vagy bejósolhatóság érzését biztosító mechanizmusok közbe nem lépnek. Ezek között a jelentéstulajdonítás kiemelt szerepet játszik (Kulcsár, 2009). A vallási vagy elfogadó attitúd, az „értelemadás” a kontroll észlelésének élményét tudja nyújtani még a reménytelennek túnő állapotokban is. Éppen ez lehet az egyik kulcs ahhoz, hogy a traumatizáció ne a PTSD felé induljon el, hanem a poszttraumás növekedés irányába. A kontroll megélése, a PAG ventrolaterális oszlopait aktiválja, ami a tehetetlenség kiváltotta opiát analgéziát endokannabinoid analgéziába tudja fordítani. Ez szintén fájdalomcsökkenéssel jár, de szemben az endogén opiátokkal a hatás nem csap át a későbbiekben hiperalgéziába (trauma utáni fokozott fájdalomérzékenység) annak káros következményeivel együtt (Kulcsár, 2009). 
A poszttraumás növekedés hátterében, szemben a trauma kiváltotta felfokozott emocionális válaszkészséggel, annak kompenzációjaként, a kontrollfunkciók felerősítésének kísérlete áll, ami összefügg a prefrontális funkciók aktivációjával (Kulcsár, 2009).

A poszttraumás növekedésben kulcsszerepe van az inzulának. Az inzuláris régió „mint a viscerális és szociális agy találkozási felülete” (Kulcsár, 2009, 127.o.) meghatározó szerepet játszik a társas hatások közvetítésében, értve ezalatt a szociális traumák negatív, vagy a társas támogatás pozitív hatását. Kulcsár (2005) hipotézise szerint az inzula múködése összefüggésbe hozható a pszichoszomatikus zavarok patogenezisével és a testi betegségek pszichoterápiájának hatásmechanizmusával. Az inzula fokozott aktivációt mutat a szeretet átélése alatt (Bartels \& Zeki, 2004), pozitív társas hatások, mint a szerelem, az anyai szeretet érzésének indukálásakor. Ugyanekkor a viselkedéskontroll szervezéséért felelős orbitofrontális kéreg aktivitása is fokozódik, akárcsak a fentebb ismertetett PAG múködése, ami a fájdalom centrális szabályozásában játszik szerepet. Bartels és Zeki (2004) rámutattak, hogy az érintett áreák oxitocin és vazopresszin receptorokban gazdag területek, ezek a neurotranszmitterek pedig a társas viselkedés és társas késztetés neurokémiai közvetítői.

Az inzula szerepe az én-nem én átélésében is jelentős (Kulcsár, 2005), mivel „megnyitja” az énhatárokat. A „nyitott-én” kapcsolatba léphet a transzcendenssel, ami poszttraumás növekedéshez, illetve spirituális élmények megjelenéséhez vezethet. A „Mindenható”, az „Egység” iránt érzett bizalom és elfogadás megóv az emberekben való csalódás károsító hatásától, és a tehetetlenség érzésétól. Az énközpontúság meghaladása, a nyitott-én a szuggesztibilitás növekedésével jár. „A szuggesztív hatásokra való érzékenység és az inzula viszonyát megerősíti, hogy az inzula az emocionális/ viscerális tükörneuronrendszer, ezzel együtt az empátiáért felelős agyi rendszer része" (Kulcsár, 2009, 127. o.).

Mindezekből láthatjuk, hogy a krízisben lévő, traumát átéló embernek elsősorban a kapcsolódás, a szeretet interperszonális megtapasztalása segít - akár társas, akár a transzcendens dimenzióban -, és ez lehet az út a poszttraumás növekedés felé, szemben a poszttraumás stresszbetegség kialakulásával.

\subsection{Féltekei lateralizáció}

A féltekei lateralizáció és a stresszhatások összefüggéseit különösen a pszichoszomatikus tünetképződés vonatkozásából tartom fontosnak röviden áttekinteni. Az implicit emóciószabályozási stratégiák, amelyek a korai „szimbiotikus" életszakaszban bontakoznak ki, a jobb féltekei múködéshez kapcsolhatók (Greenberg, 2008). A szabályozás ezen a szinten nem tudatos, 
hanem automatikus testi reakciókhoz, múködésekhez kötött. A kialakuló érzelemszabályozási deficitek azon túl, hogy tartós funkcióromlást okoznak (Eisenberg és mtsai, 2010), erősen kötődnek a testi érzetekhez, és gyakran pszichoszomatikus tünetképződés formájában jelentkeznek. Kulcsár (1993) is hangsúlyozza, hogy a jobb félteke speciálisan alkalmas az interoceptív input felvételére, múködése szubjektívebb, azaz állapotfüggó és egyúttal regresszívebb is. Érintkezése a szomatikus-viszcerális történésekkel a korai szimbiotikus életszakasz továbbélése. A pszichoszomatikus „átfordulás”a külső és belső élmények összekapcsolódása, jobb féltekei múködésmódot feltételez. A stresszhelyzet egy határon túl regresszív állapot megjelenését provokálja, azaz jobb féltekei üzemmódot implikál, ami veszélyeztet a pszichoszomatikus tünetképzésre (Rossi, 1986; idézi: Kulcsár, 1993).

Mindenfajta regresszív állapot, így a jobb féltekei dominancia is (és ezzel összefüggésben a tartós stressz indukálta változások), egyszerre lehetőség és veszély. A külső és a belső „információ illesztésekor a kortiko-limbikus kapcsolatok átrendezése történik", ami sérülékennyé teszi a nyitottá váló szabályozómechanizmusokat (Kulcsár, 1993, 31. o.). Előnye elsősorban a szimbolikus reprezentáció, az elaboráció, a kreativitás lehetősége, veszélye pedig a pszichoszomatikus sérülékenység.

Shore $(2012 ; 2014)$ álláspontja szerint a jobb félteke nemcsak a korai kötődésben játszik kulcsszerepet, hanem a későbbiek során - a terápiás munkában is - alapvető „kapu” az érzelemszabályozási kapacitás növekedéséhez, fejlődéséhez. A terapeuta-páciens kapcsolat folyamán Badenoch (2008) alapvetően fontosnak tartja a kapcsolat mindkét résztvevőjénél a jobb féltekék aktivitását, azok összehangolódását. A terapeuta számára a saját és a kliens implicit emocionális folyamataira való együttes fókusz fejlesztése elengedhetetlen. A téma részletes elemzése Vas (2007) tanulmányában olvasható, a kétszemélyes pszichoterápia hatótényezőivel kapcsolatban.

\section{A segítségnyújtás lehetőségei}

\section{1. Általános megfontolások}

A fentiek alapján elmondható, hogy a krízisállapotokkal, illetve traumatikus eseményekkel együttjáró intenzív vagy elhúzódó stresszreakció egyik jelentős maladaptív hatása az érzelmi reguláció egyensúlyának megbomlása. A krízisellátás a pszichológiai tanácsadás kompetenciaköréhez tartozó egyik alapvető feladat, ezért a krízis következtében kibillent érzelmi reguláció helyreállításának támogatása a tanácsadás fontos fókusza lehet. Elsőként a sürgősségi ellátásban, a krízisintervenció során, másodsorban a traumafeldolgozást megelőzően, a traumaterápia első, ún. stabilizációs fázisában tudjuk támogatni a kliens érzelemregulációját. 
Roberts és Ottens (2005) integrált intervenciós modelljében (ACT-modell: Assessment - Crisis intervention - Trauma management) az akut krízis és traumaellátás három stádiumát vázolja fel: elsóként a helyzetfelmérést, ezt követően a krízisintervenciót, majd a traumatikus következmények kezelését. A krízisintervenció lényeges eleme a klienshez való kapcsolódáson túl az érzelmek explorációja és kifejezésének segítése, továbbá a megváltozott arousalállapotok és a stresszreakció kezelése. Ez a negyedik lépcsőfok a Roberts (2000) által leírt hétlépéses krízisintervenciós folyamatban. A krízisintervenció módszertanáról, lépéseiről alapos összefoglalót olvashatunk a Csürke és munkatársai (2014) szerkesztette Mindennapi kríziseink címú könyvben.

Van der Kolk, Roth, Pelcovitz, Sunday és Spinazzola (2005), valamint Lanius és munkatársai (2010) szintén az érzelmi regulációs készségek helyreállításának fontosságára hívják fel a figyelmet. A traumatizált személyeknél - különösen a krónikusan traumatizáltak esetében - egyrészt és elsőként az érzelmi regulációs készségek, skillek támogatása a feladat, mivel a legtöbb és legzavaróbb tünet ezek hiányosságaihoz kapcsolódik (acting out, disszociatív állapotok, kapcsolati nehézségek, stb.). Csak ezután, az ún. stabilizációs fázis után javasolják a traumatikus élményekhez tartozó károsodott memóriafolyamatok és az ezeken alapuló kognitív tartalmak átdolgozását (reprocessing), egybevágóan a Pierre Janet (1919) által korábban leírt traumafeldolgozási stádiumokkal (Van der Hart, Brown, \& Van der Kolk, 1989).

Ahogy a korábbiakban láthattuk, az érzelmi regulációs folyamatok az arousalkontinuum mentén két szélsóség irányába tolódhatnak el: extrém magas arousal szimpatikotóniával, amit paraszimpatikus hiperrekció követ, ha a szimpatikus „küzdj vagy menekülj” akció nem vezetett eredményre. A paraszimpatikus „átcsapás” az arousalszint visszaesésével (hipoarousal) és disszociatív tünetek (pl. freezing-reakció) megjelenésével jár.

Mindkét esetben jelentősen szúkül a személy érzelmi tolerancia-ablaka (Ogden \& Minton, 2000; Ostacoli \& Bertino, 2015; Siegel, 1999). A tolerancia-ablak tartományait a 2. ábra mutatja be. A segítségnyújtás célja az aktivációs szint és ezáltal az érzelmi reguláció egyensúlyának helyreállítása, hoszszabb távon pedig a tolerancia-ablak tágítása (Ostacoli \& Bertino, 2015).

Gonzalez (2016) előadásában találhatunk egy olyan - az EMDR-terápia használata során is alkalmazott - szempontsorozatot, amely jó támpontokat nyújthat a különböző típusú regulációs nehézségek kezeléséhez. A megközelítés lényege, hogy az alulkontrollált hiperarousal állapotoknál a terapeuta (segítő szakember) célja a prefrontális aktivitás fokozásának facilitálása, illetve az inadekvát kompenzációs stratégiák változtatása, míg a túlkontrollált, hipoarousal állapotok esetén a kapcsolódás, biztonságérzet támogatása, valamint az emóciók kezelésének kognitív modulálása (Gonzalez, 2016). 
A viselkedési stratégiák változtatása segíthet a tehetetlenség oldásában, úgymint a prefrontális aktivitás vezérelte kontrollfolyamatok múködésének elősegítése hiperarousal állapotban, illetve a kapcsolódás megélésének élménye hipoarousal állapotban. Mindez egybecseng a poszttraumás növekedés és az észlelt kontroll kapcsán bemutatott Kulcsár (2009) által fentebb leírt elképzeléssel.

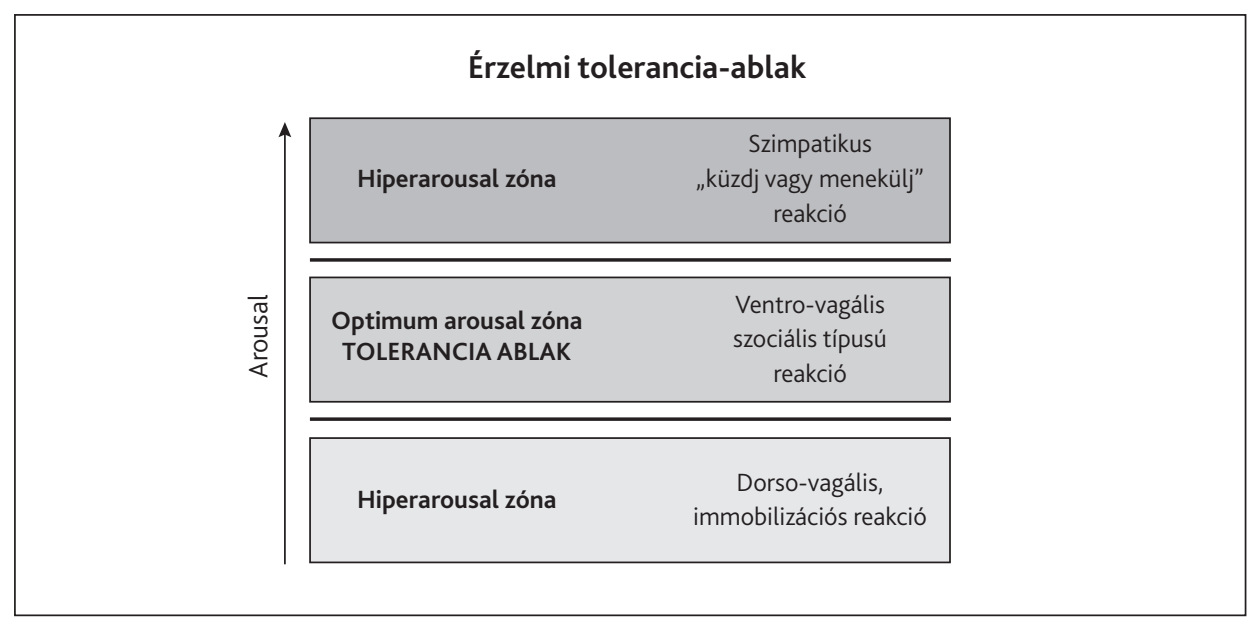

2. ábra. Érzelmi tolerancia-ablak (Gonzalez \& Mosquera, 2011;

illetve Ogden \& Minton, 2000 nyomán)

\subsection{Egyénre szabott önsegítő terv kidolgozása}

Ahhoz, hogy hatékony segítséget nyújthassunk az akut stressz, krízis, traumatizáció okozta érzelmi reguláció helyreállításához, mindenekelőtt ismernünk kell a kliens alapvető érzelemregulációs stratégiáit. A klienssel közösen fel kell térképeznünk, hogy melyek azok a speciális triggerek, körülmények, amelyek a személy biztonságát veszélyeztetve, stresszreakciót kiváltva - akár traumatikus emléket aktiválva - megzavarják az érzelemszabályozást.

Alapvető szempont maga a kapcsolódás a klienssel, annak mikéntje, hiszen a poszttraumás állapot megelőzése, illetve az esetleges traumák pszichés következményeinek gyógyítása csak biztonságot nyújtó kapcsolatokon keresztül múködhet (Pohárnok \& Lénárd, 2015).

A kapcsolati biztonságon túl szintén fontos, hogy a kliens a saját testében is biztonságban érezhesse magát, azaz visszanyerhesse a kontrollt a különböző poszttraumatikus tüneteket produkáló, érzelmi szabályozási deficiteket mutató teste felett (Láng, 2015). 
Tudnunk kell, hogy az érzelmi reguláció aktuálisan fennálló zavara milyen típusú, azaz alul- vagy túlszabályozás a jellemző reakciómód, illetve ezek hogyan váltakoznak. Hozzá kell segítenünk a személyt ahhoz, hogy megismerje a helyreállítás lehetőségeit, például olyan speciális gyakorlatok elsajátításával, amelyeket eredményesen tud alkalmazni azokra a helyzetekre, ahol a korábbi megküzdési stratégiái alkalmatlanok. Fel kell tárni és bővíteni a személyes rezilienciafaktorokat, a megküzdési készségeket. Krónikus traumatizáció esetében a negatív gondolati minták (automatikus negatív gondolatok) azonosítása is szükséges, mert ezek aktiválódásával a diszfunkcionális érzelmi körök múködésbe lépése beindíthatja az érzelmek diszregulációját. Minden esetben hasznos lehet - a helyzethez mérten alkalmazott - pszichoedukáció. ${ }^{1}$

Még egyszer hangsúlyoznám, hogy az érzelmi reguláció támogatása, különösen traumák esetén, nem elegendő a pszichés múködések helyreállításához, viszont a stabilizációs fázis részeként fontos, sőt nélkülözhtetlen elökészületet jelenthet a későbbi traumafeldolgozáshoz (Van der Kolk és munkatársai, 2005).

A szociális munka területén régóta ismert az egyéni öngondoskodási terv készítése ${ }^{2}$, ilyen példákat láthatunk a New York-i Buffalo University ${ }^{3}$ és a University of Calgary ${ }^{4}$ honlapján: lépésról-lépésre segítik a személyt egy ilyen típusú terv megalkotásában. Ebből a tervből mutat egy összefoglaló táblázatot a 3. ábra. A jól strukturált készenléti terv vagy eszköztár hatékony segítséget jelenthet bárkinek az általános értelemben vett stresszkezelésben, de krízis- és akut stresszhelyzetben is. Az új technikák elsajátítása, begyakorlása pszichoedukációval kiegészítve fontos prevenciós lépés a későbbiekben esetlegesen fellépő, a szokásos megküzdési repertoárt meghaladó, kihívást igénylő helyzetek esetén is.

Ugyanakkor a szociális munka terén alkalmazott, elsősorban a gyakorlatra koncentráló szemlélet mélységében nem nyújtja azt az átfogó megközelítést, amely az érzelemszabályozási anomáliákat, azok idegrendszeri háttérmechanizmusait összekapcsolja az egyes helyzetekben javasolt gyakorlatokkal. Ha átlátjuk, hogy például egy kritikus életesemény, traumatizációs folyamat milyen idegrendszeri múködések mentén hat az érzelmi szabályozásra, akkor a helyreállítást célzó gyakorlat kiválasztása is adekvátabb le-

\footnotetext{
1 Why self-care plan is crucial to trauma therapy. Letöltve: 2018. 01. 12-én: https:/ / medium.com/ @ odelya/why-self-care-plan-is-crucial-to-trauma-therapy-928b092fa0da\#.jwy5hggfl

2 Self-care exercises and activities. Letöltve: 2017. 06. 24-én: http:/ /socialwork.buffalo.edu/resources/ self-care-starter-kit/self-care-assessments-exercises/exercises-and-activities.html

3 Introduction to Self-Care. Letöltve: 2018. 01. 12-én: https:/ / socialwork.buffalo.edu/resources/ self-care-starter-kit/introduction-to-self-care.html

4 Self-Care Starter Kit, Letöltve 2018. 02. 10-én: https:/ /www.ucalgary.ca/wellbeing/files/ wellbeing/self-care-starter-kit.pdf
} 
het. Ezt a szintézist kísérlem meg a következőkben. Néhány típusgyakorlat bemutatásával szemléltetem a különböző arousalállapotokban javasolt technikákat.

A tolerancia-ablakon (Siegel, 1999) kívül eső arousal állapotokban alkalmazhatók ún. „bottom-up”, azaz alulról-fölfelé, a testtól, illetve a szubkortikális agyi régiók felől az agykérgi strukturák irányába ható gyakorlatok. Ez a megközelítés összecseng azzal, amit az idegrendszer neuroszekvenciális fejlődése kapcsán Perry és Dobson (2014) megfogalmaztak, vagyis, hogy a sérült múködések regenerációja, illetve az éretlen idegrendszeri múködések fejlesztése az alsóbb agyi régiókkal, illetve a test bizonyos funkcióival (légzés, mozgás, stb.) kapcsolatos gyakorlatok során valósítható meg. Ugyancsak alkalmazhatók „,top-down”, azaz felülról lefelé, az agykéreg felől a szubkortikális területek irányába hatást kifejtő gyakorlatok is, amelyek elsősorban a kognitív funkciókra épülnek. A következőkben mindkét gyakorlattípusra olvashatók példák.

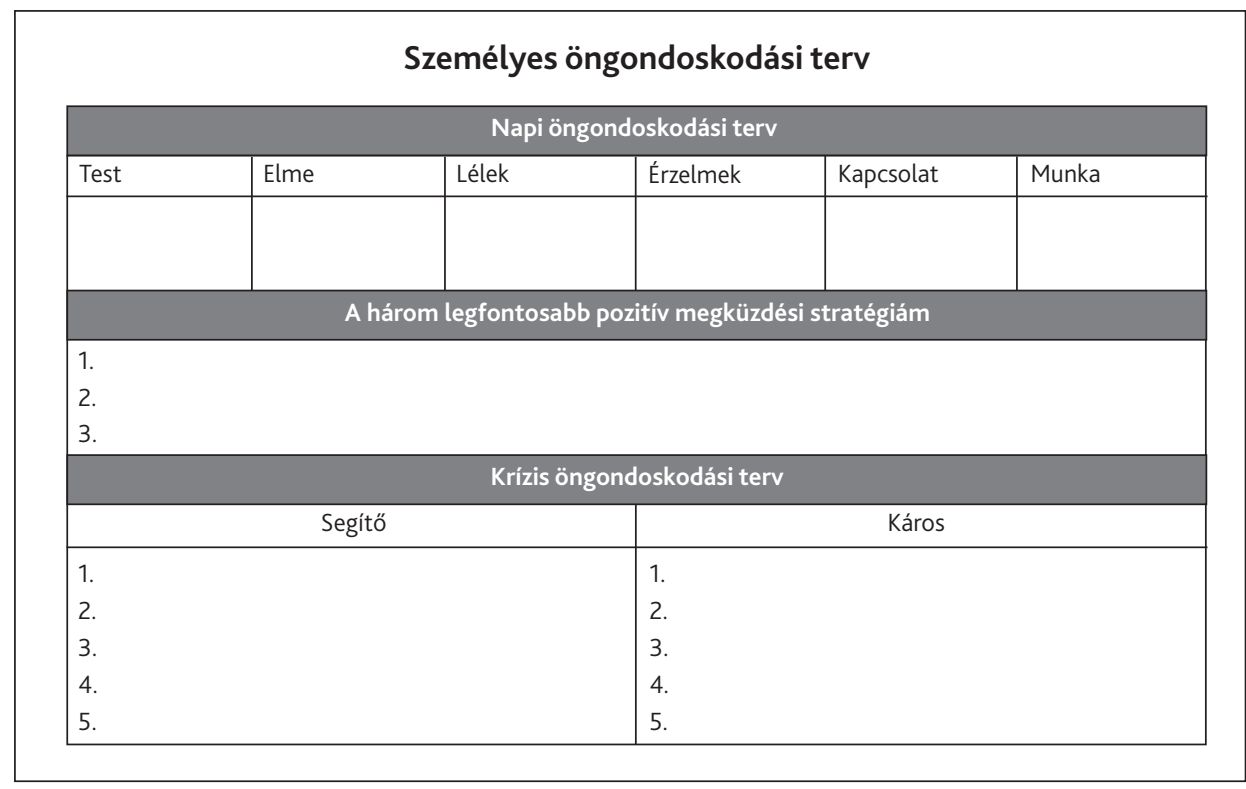

3. ábra. Összefoglaló tervlap egy öngondoskodási munkafüzetből (homewoodhealth.com)

\section{Hiperarousal állapotokban javasolt gyakorlatok, technikák}

Hiperarousal állapotban a prefrontális gátló aktivitás csökken, ezért a kéreg alatti, elsősorban limbikus struktúrák aktivációja révén magas arousalszint mellett a vegetatív idegrendszer szimpatikus aktivitása dominál. 
Az esemény elmúltával is fennmaradó, vagy bizonyos triggerekre kiváltódó szimpatikus arousal csökkentése megvalósítható az elsődlegesen a prefrontális kérget aktiváló „,top-down” technikákkal, mint amilyenek pl. a munkamemóriát igénybe vevő kognitív feladatok. Ugyanakkor jól múködnek a "bottom-up" indítású (azaz testi múködéseket aktiváló) gyakorlatok is. Ez utóbbiak azért is előnyösek, mert minimális verbalitást igényelnek, ami egybecseng azzal, hogy krízis- vagy poszttraumás állapotokban a verbalitás kevésbé jól funkcionál (Hull, 2002). A nonverbális technikák tudatos alkalmazása, illetve a velük tapasztalt élmények későbbi átbeszélése támogatja az érzelemszabályozás implicit és explicit folyamatai közötti (Greenberg, 2008), valamint a különböző típusú memóriarendszerek közötti (Kulcsár, 2009) kapcsolat létrejöttét.

\subsection{Légzőgyakorlatok}

A szimpatikus idegrendszer megnövekedett aktivációja közvetlenül légzőgyakorlatok útján is csökkenthető bizonyos mértékben. Zelano és munkatársai (2016) EEG-vizsgálatukban kimutatták, hogy drasztikus különbség van az amigdala és a hippokampusz aktivitásában a belégzés és a kilégzés alatt. Belégzéskor mindkét régió, illetve az egész limbikus rendszeri múködés aktívabb, mint kilégzéskor. Ugyanígy veszélyhelyzetben, szimpatikus idegrendszeri aktivációnál gyorsul a légzésritmus, nő a belégzés ideje, szemben a nyugalmi állapottal (Zelano és mtsai, 2016).

Hiperarousal állapotban ezért az egyenletes ritmusú, mély légzés, illetve a kilégzés hosszának növelése a cél. A gyakorlat paraszimpatikus áthangolódást, ventrovagális múködést indukál (Porges, 2009). A légzőgyakorlatok lényege ezért a kilégzés, illetve a légzések közötti szünet nyújtásának növelése. Tudatos alkalmazás esetén a „bottom-up” hatás mellett érvényesül egy „top-down” effektus is, mivel a légzésre való figyelem a prefrontális kéregterületek „mozgósításásával”, azok kontrollfunkcióját növelve gátolja a limbikus aktivitást. A relaxációs, meditációs, mindfulness technikákban fontos szerepe van a tudatos légzésnek. Számos légzéstechnika létezik, amelyek célja a megnyugvás, a paraszimpatikus áthangolódás elérése. Ezek közül példaként említeném meg a „Négyszög-légzést", ${ }^{5}$ amelynek lépései a következők:

1. Elindulunk egy képzeletbeli négyszög egyik sarkából, mintha a négyszög oldalán haladnánk a következö sarokig, 4-ig számolva beszívjuk a levegöt.

2. A második saroktól a harmadikig 4-ig számolva bent tartjuk,

5 Biró, E. (2016). „Csak egy pohárkával!...” - EMDR terápia alkalmazása addikciókban. Előadás a Magyar EMDR Egyesület 2016. évi szimpóziumán, Budapest, 2016. 02. 06. 
3. majd a harmadiktól a negyedik sarokig kifújjuk.

4. A negyedik és első sarok közötti távon szünetet tartunk a következö lélegzetvétel kezdetéig, szintén 4-ig számolva.

\subsection{A feszültség (aktivációs mintázat) „átcsatornázása”}

A magas arousalszint sok esetben nem csökkenthető közvetlenül légzővagy relaxációs gyakorlatokkal, mert a személy nem képes azonnal áthangolódni a nyugalmi állapotra. Ilyenkor hatásosabb az energia átalakítása, csatornázása. A szimpatikotóniával járó izomtónus növekedés, a „harcolj vagy menekülj" állapot magasabb arousalszintjével felhalmozódó energiatöbblet levezetésére alkalmasak lehetnek elsősorban a mozgásos gyakorlatok (pl. „brain gym” technikák), a mozgás- és táncterápiák, imaginációs gyakorlatok, múvészetterápiás megközelítések (zene-, képzőmúvészetterápiás formák).

\subsubsection{Mozgáson (ritmus, egyensúly) alapuló technikák}

Akut hiperarousal állapotban, de a stresszkezelés hosszabb távú megalapozásában is jól alkalmazhatók a mozgásos gyakorlatok, amelyek részben "bottom-up" folyamatok révén, azaz a testi reakciók, bizonyos mozdulatok elvégzése útján, másrészt a mozgásvezérlésben szerepet játszó kérgi szabályozás, figyelmi folyamatok involválása révén („,top-down”) fejtik ki regulációmódosító hatásukat. Egyes mozgáselemek a jobb-bal féltekei aktiváció kiegyenlítódését célozzák.

A „brain gym” technika speciális mozdulatsorok végzését jelenti. Olyan fejlődésneurológiai szempontokon alapuló módszer (Diamond, 2001), amelynek elsődleges célja a gyermekkori figyelmi és tanulási zavarok kezelése volt (Brown, 2012; Dennison \& Dennison, 2010), de széles körben alkalmazzák feszültségoldásra, valamint a figyelmi és a koncentrációs képesség fokozására a felnőtt populációban is (Koelman, 1997).

Az ún. pszichogimnasztikai - izommozgásokon, bizonyos mozdulatsorok elvégzésén alapuló - gyakorlatok szintén alkalmazhatók a mentális egészség fenntartásában (gyermekeknél: Zentainé Kriszt, 1997), a stresszkezelésben, és speciálisan a sürgősségi helyzetekben is (Nagy, 2016).

Említés szintjén fontosnak tartom megjegyezni, hogy az idegrendszer érését és rehabilitációját támogató egyik mozgásos módszer az RGM (Ronnie Gardiner Módszer), amely egy multiszenzoros terápiás és fejlesztó eljárás, zenére végzett speciális koreográfiák tanulását és gyakorlását jelenti, amelyek fejlesztik a motoros és kognitív képességeket, a memóriát és a kon- 
centrációt. Az RGM 1993 óta ismert, elsősorban Svédországban (Gardiner, Jaspers, \& Jaastad, 2014). Szintén hasznosnak találták a módszert a stroke utáni felépülésben (Schütz, 2002), Parkinson kórban (Pohl, Dizdar, \& Hallert, 2013) és depresszív állapotokban is.

Számos „mind-body” technika - fizikai aktivitás, jóga, thai-chi, mindfulness alapú meditációs módszerek - gyermekkori figyelemzavarban mutatott hatékonyságáról szóló tanulmányt tekintett át Herbert és Esparham (2017). Egyik fontos megállapításuk szerint azoknál az ADHD-s gyerekeknél tapasztaltak jobb eredményeket, akiknek a szülei is alkalmazták a mindfulness technikákat a gyermekneveléssel kapcsolatban.

Az aktív sport, nagymozgásos aktivitások természetesen szintén jó módszerként szolgálnak a hiperarousal állapotok mérséklésére.

\subsubsection{Müvészetterápiás módszerek}

A különböző modalitású múvészetterápiás módszerek (képzőmúvészeti technikák, zeneterápia, mozgás- és táncterápiák, stb.) is támogatják a stresszkezelést (Clow \& Fredhoi, 2006), az emóciószabályozást akár akut helyzetben, de hosszabb távon is. Az érzelmi regulációs zavarok mindkét típusánál alkalmazhatók, facilitálják a két félteke harmonikus együttmúködését, az emóciók megjelenítését, tartalmazását, átalakítását és a verbalitással való összekapcsolását is. Bolwerk, Mack-Andrick, Lang, Dörfler és Maihöfner (2014) fMRI vizsgálat során kimutatták, hogy a múvészetterápiás foglalkozások kifejezetten jótékony hatásúak idős korban: a 60 év feletti résztvevők rezilienciaszintjének növekedését tapasztalták a frontális és parietális kéreg konnektivitásával összefüggésben.

A múvészetterápiás módszerek egyszerre múködtetik az idegrendszer „bottom-up" és „top-down” regulációját, mivel a finom-, illetve nagymotoros testmozgások során kifejezésre jutó érzelmek megjelenítését verbalizáció követi - egyéni vagy csoportos megbeszélés -, ami segíti azok tudatosulását, az élettörténeti háttér megértését, a keletkezett érzelem, testemlék autobiografikus memóriatárba illesztését.

Hazánkban Antalfai Márta katarzis-élményre épülő tematikus müvészet-pszichoterápia módszere (Antalfai, 2007; 2016) részletesen taglalja, hogy milyen módon fejt ki egészségmegőrző, gyógyító hatást a módszer. „Hatására fejlődik és differenciálódik az érzelmi és akarati élet, a megérző és beleélő készség, valamint a tudat felismerő képessége" (Antalfai, 2007, 3. o.).

Néhány alapszabály betartása mellett a múvészet-pszichoterápiában alkalmazott technikák a pszichológiai tanácsadás során mind az exploráció (első interjú), mind az intervenciók során alkalmazhatók. Ezek a szabályok a következők: megfelelő tér, eszközök és idő rendelkezésre bocsátása a 
kliens számára, ami jelentheti a szokásosnál hosszabb tanácsadási alkalmat, amit érdemes előre egyeztetni. Szintén fontos az értelmezés kerülése és a kontraindikációk figyelembe vétele (pl. kézsérülés, olyan hivatás, ahol napi szinten elvárt, tehát teljesítményjelleggel bír a képi ábrázolás, stb.; Gladding \& Newsome, 2003).

Az egyik legegyszerúbb technika az érzelmek megjelenítésének négylépéses módszere. A négy lépés a következő: „bemelegítés”, azaz a megjelenő probléma, nehézség, a hozzá kapcsolódó érzelem verbális megfogalmazása, körülírása, amit a megjelenítés, azaz maga az alkotás követ (bármiféle technikával, amihez eszközünk van). Harmadik lépésként a kliens elmondja, hogy mit gondol, mit lát a saját alkotásával kapcsolatban (megosztás), végül pedig a tanácsadóval közös beszélgetés zárja a folyamatot (Gladding \& Newsome, 2003).

Illusztrációként az alábbiakban bemutatásra kerül néhány alkotás. A 4. ábrán egy hiperarousal állapot (düh) megjelenítése látható. A múltból eredő, kifejezésre nem juttatott neheztelés, harag a jelenben is múködésbe lép, ha a kliens az eredetihez hasonló helyzetbe kerül. A harag mértéke sok esetben jóval nagyobb, mint amit az aktuális helyzet megkívánna. Az alkotásban megjelenő arányokat szemlélve válik szembetúnővé, hogy milyen óriási mennyiségú „sötét foltokkal teli” energia raktározódik a testben. A kliens (33 éves nő) múltbeli traumáinak feldolgozása a későbbiekben EMDR-terápiával történt. A traumaterápia stabilizációs (előkészító) fázisában fontos szerepet játszott a bemutatott technika - általa vált kifejezhetóvé és verbálisan is átbeszélhetővé a düh tematikája.

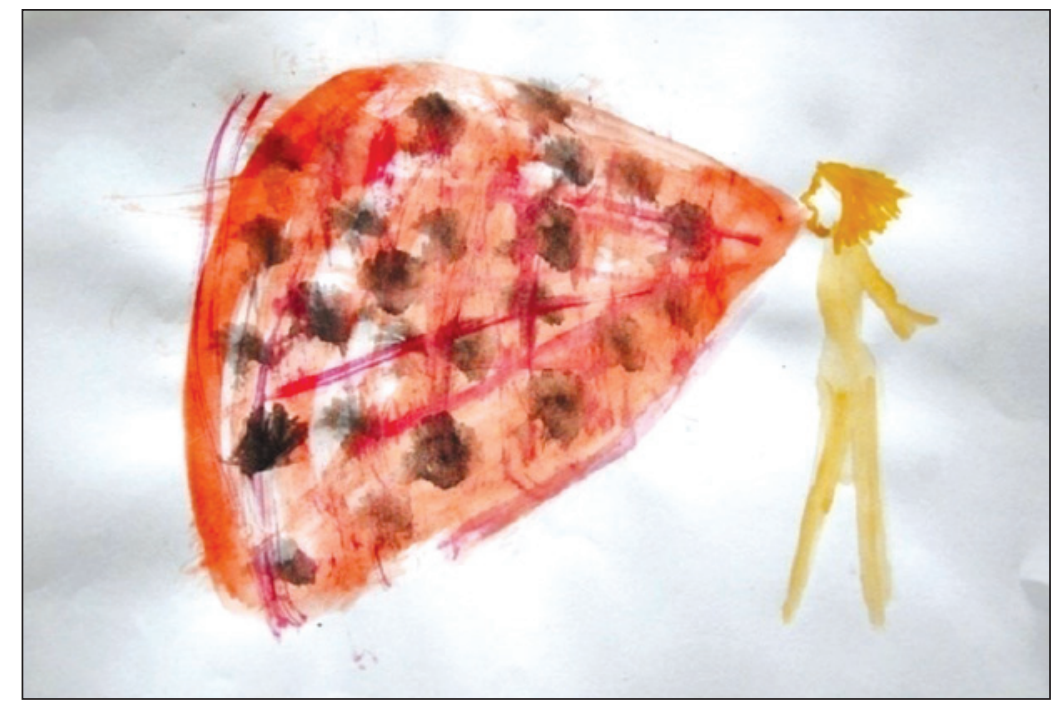

4. ábra. Düh (33 éves nő alkotása) - hiperarousal állapot megjelenítése 
A négylépéses módszer természetesen a hipoarousal tartományban fellépó érzelmek, testérzetek megjelenítésére is alkalmas. Erre példa az 5. ábrán látható alkotás, amit egy 17 éves lány készített. Gyakran fellépő „ábrándozás” (disszociatív állapot) miatt nem tudott figyelni az órákon, és egy idő után iskolába sem akart menni a romló tanulmányi eredménye miatt. A szülők nem tudtak „hozzáférni” a problémához. Pszichiátriai vizsgálat után orvosa antidepresszánst javasolt neki, állapota azonban nem javult. Az itt látható alkotás - aminek a kliens a „Lebegés” címet adta - nyitotta meg az utat a probléma átlátása felé. Képzőmúvészet-terápiás technikák mellett zeneszámok útján is „kommunikáltunk”, vagyis a verbalitás viszonylagos mellőzésével folyt a kapcsolatteremtés és a közös munka a kezdeti fázisban. Később világossá vált, hogy a kliens folyamatos kapcsolati mikrotraumáknak volt kitéve a családi rendszerben. Állapota jelentősen javult, miután az egyéni konzultációk családterápiás alkalmakkal is kiegészültek.

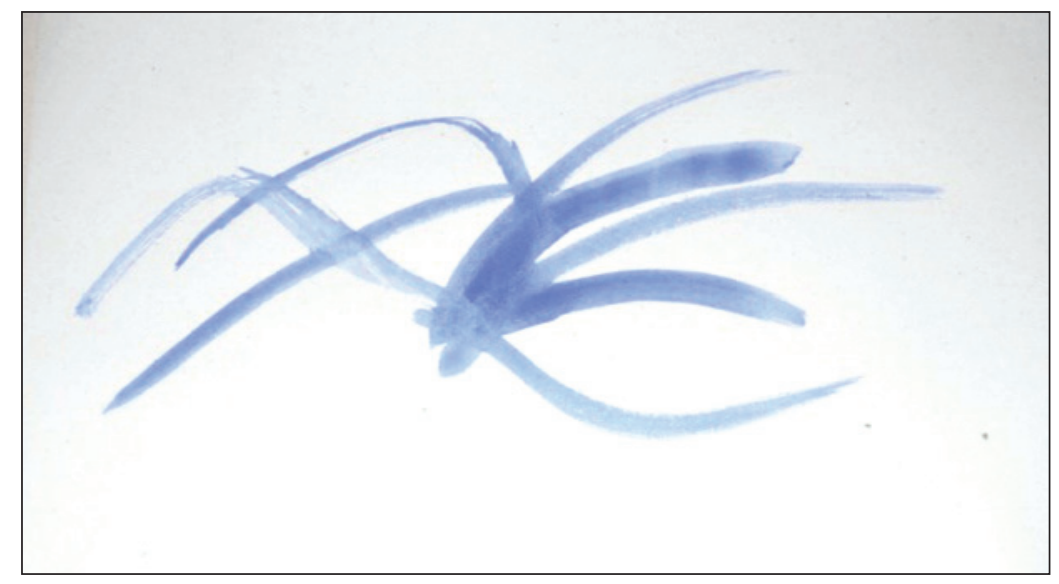

5.ábra. Lebegés (17 éves lány alkotása) - disszociatív állapot megjelenítése

Ahogy a fenti két esetvignetta is szemlélteti, a képzőmúvészet-terápiás technikák kifejezetten hasznosak lehetnek olyan esetekben, ahol a jelenben problémát okozó tünet szavakkal nehezen megfogalmazható, illetve élettörténeti háttere nem világos. Saját szakmai tapasztalatom alapján úgy találtam, hogy különösen gyerekeknél, serdülőknél, de megfelelő bevezetéssel felnőtteknél is jól múködnek. A helyesen alkalmazott négylépéses technika a kliens-tanácsadó kapcsolat építésében, a bizalmi híd megteremtésében is hasznos eszköz.

Számos tanulmány utal arra, hogy traumát átélőknél - például menekülteknél - szintén nagyon hatásos eszköze lehet a traumaterápiának a múvé- 
szetterápiás megközelítés önmagában is, illetve más módszerekkel együtt alkalmazva (Kalmanowitz \& Ho, 2016). Gáti (2002) a képzőmúvészet-terápia pszichiátriai betegek pszichoterápiájában való alkalmazását mutatja be doktori értekezésében, hangsúlyozva, hogy a múalkotás létrejötte segíti a szelfkohézió kialakulását és annak korrekcióját.

\section{Hipoarousal állapotokban javasolt gyakorlatok, technikák}

Az idegrendszeri aktiváció hipoarousal zónájában a félelemmel kapcsolatos érzelmek (erôs szorongás, rettegés) és testérzetek (remegés, zsibbadás, hányinger, stb.), illetve disszociatív reakciók (érzéskiesés, freezing, ájulás, stb.) jelentkeznek. Ilyenkor az extrém mértékú elárasztottság miatt a prefrontális régiók múködése „szétkapcsolja” az információfeldolgozást, az érzelmek és testérzetek átélése ármenetileg, különböző mértékben gátlódik (Lanius és mtsai, 2010).

Ebben az esetben az „újrakapcsolódást” elsősorban és első lépésként a biztonságérzet megteremtésével tudjuk facilitálni (Van der Hart, 2012). A biztonságot nyújtó helyzet (személy, körülmények) a hoemeosztázis egyensúlyának helyreállítását, a paraszimpatikus (ventro-vagális) túlsúlyú vegetatív szabályozást segít visszaállítani (S. Nagy, 2009).

Akut stressz- vagy katasztrófahelyzetben elsődleges a kapcsolatteremtés, és ha ez létrejön, következhetnek az érzelmek regulációját célzó intervenciók; ugyanakkor már maga a kapcsolatteremtés is tekinthetó érzelmi regulációs lépésnek. Mivel krízisben, traumatizáló helyzetben nő a szuggesztibilitás, az énhatárok az inzula fokozott aktivitásával párhuzamosan megnyílnak (Kulcsár, 2005), ezért a következményeket tekintve egyáltalán nem mindegy, hogy az akut stressz állapotban, krízisben lévő személy talál-e kapcsolódást, és hogy a kapcsolódás milyen minőségú. A segítőnek képesnek kell lennie az emóciók, élmények tartalmazására és az együttérzés kifejezésére, ahhoz, hogy a kliens érzelemszabályozása a megnyugvás, újrakapcsolódás irányába módosuljon.

\subsection{Biztonságérzet növelése}

\subsection{1. „Földelés”}

A biztonságérzetet, stabilizációt „alulról-fölfelé” támogató gyakorlatok közé tartoznak, az ún. self-contact, vagy self-holding gyakorlatok. Ezek egyik típusa a saját test, testrészek tudatos érzékelése - pl. érintéssel vagy 
enyhe nyomásgyakorlással (Grandin, 1992) -, illetve a testrészek különböző felületekkel való érintkezésének (pl. talp a talajon, combok a széken, stb.), azaz a jelenlét fizikai dimenziójának átélése.

Szintén a disszociatív állapotok ellen hat az „itt és most” jelenlévő ingerek számbavétele, érzékelése - a látás, hallás, szaglás, ízlelés, tapintás aktivizálása. ${ }^{6}$

\subsubsection{Relaxációs, meditációs módszerek}

A relaxációs módszerek gyakorlása az idegrendszert hosszabb távon is hozzásegíti a paraszimpatikus áthangolódáshoz, ezáltal a kiegyensúlyozottabb múködéshez, a stabilabb érzelemszabályozáshoz. Az autogén tréning (Bagdy \& Koronkai, 1988) jótékony hatásai régóta ismertek, ezért ebben a cikkben erre a módszerre nem térek ki.

A közelmúltban egyre elterjedtebbé váló mindfulness gyakorlatok hatásáról is számos tanulmány készült. Egy metaanalízis eredményei szerint a rendszeres gyakorlás pozitív hatással van a vitalitásra és a megküzdésre (Grossman és mtsai, 2007). Davidson és munkatársai (2003) randomizált, kontrollált EEG vizsgálata szerint a mindfulness gyakorlása kimutatható változásokat idéz elő a bal oldali anterior kérgi régiókban, csökkenti a szorongást és javítja az immunfunkciókat. A mindfulness meditáció csökkenteni képes például a fájdalomérzés intenzitását is az orbitofrontális és cinguláris kérgi aktivitás növekedése mellett (Zeidan és mtsai 2015). Goldberg és munkatársai (2018) metaanalízist végeztek a mindfulness alapú stresszcsökkentó módszerek (MBSR) hatékonyságának vizsgálatára. Eredményeik szerint a módszer egyértelmúen előnyösnek bizonyult a depreszszió, a fájdalommal járó állapotok, a dohányzás és a függőségek kezelésében. A legújabb kutatások szerint a hosszú távon gyakorolt mindfulness meditáció csökkenti az amigdala reaktivitását, és növeli a funkcionális öszszeköttetést az amigdala és az érzelemregulációban jelentős szerepet játszó ventromediális prefrontális kéreg (VMPFC) között (Kral és mtsai, 2018).

A mindfulness gyakorlatok közé tartozik a jól ismert meditáció mellett a testpásztázás is, ami a testrészek képzeletbeli „számbavételét”, és az azokra való figyelmet jelenti. Ez a gyakorlat pszichológiai tanácsadás keretében is elsajátítható és otthon is gyakorolható. Különösen hatékonynak találtam elalvási vagy átalvási nehézségek esetében.

6 The 5 Step Self-holding Exercise. Letöltve: 2018. 02. 11-én: http://www.new-synapse.com/aps/ wordpress $/ \mathrm{p}=616$ 
A napi szinten ismételt ülő vagy sétálómeditáció hosszabb távon fejti ki paraszimpatikus áthangoló hatását. Vannak olyan kutatások, amelyek kimutatták a rövid távon, pár napig alkalmazott meditáció fáradtság- és szorongáscsökkentő, valamint hangulatjavító és munkamemóriát támogató hatásait (Zeidan és mtsai, 2010).

Szintén számos kutatás támasztja alá a természetben eltöltött idő fontosságát, ami a paraszimpatikus áthangolódással együtt az immunfunkciókra is jótékony hatást gyakorol (Li, 2010). Magyarul „erdőterápia” néven kezd ismertté válni ez a relaxációs metódus (Ivens, 2018).

\subsubsection{Imaginációs technikák}

Van der Hart (2012) hangsúlyozza, hogy a disszociatív tüneteket mutató személyek imaginatív fogékonysága magas, azaz könnyen bevonódnak az imaginációs gyakorlatokba.

A képzeleti tevékenységet igénylő imaginációs gyakorlatok megnyugtató képek felidézésével törekszenek a nyugalmi paraszimpatikus hatás előidézésére. A képzeleti képek a szomatikus lereagálást is helyettesíthetik (Kulcsár,1993), a jobbfélteke „átkapcsolását” a patogénből az élményfeldolgozó-konstruktív-terápiás munkamódba. A meditáció és az ima hasonló módon hat (Kulcsár, 1993).

Példaként említhetők az ún. erőforrás gyakorlatok, ezek közül legismertebb talán a fa-, illetve a vízmeditáció (Boon, Steele, \& Van der Hart, 2011).

Szintén alkalmazhatjuk a biztonságos hely gyakorlatot (Shapiro, 2016; Van der Hart, 2012) is, amelynek az a lényege, hogy a kliensüket egy olyan hely elképzelésére instruáljuk, ahol jól érezné magát, képes lenne megnyugodni, ellazulni. A biztonságérzet a hely minél többféle szenzoros modalitásának elképzelésével, illetve a saját testérzetek átélésével mélyíthető, fokozható. Hívószóval való összekapcsolással, később gyorsan felidézhetôvé tehetó maga az állapot, a vegetatív nyugalom. Különösen gyerekeknél, de felnőtteknél is kiegészíthető a gyakorlat az elképzelt hely vagy állapot lerajzolásával, megfestésével.

\subsection{A megnyugvást, paraszimpatikus áthangolódást hosszabb távon elősegítő gyakorlatok}

Ezek a gyakorlatok akkor válhatnak valóban hatásossá, ha rendszeresen ismételjük, szokássá alakítjuk őket. 


\subsection{1. Önegyüttérzés-, illetve együttérzés-gyakorlatok}

A stresszállapot kezelésében hasznosak lehetnek a "self-compassion” (együttérzés önmagunkkal) gyakorlatok (Kulcsár, 2009; Neff, 2014; Neff \& Davidson, 2016). A kifejezés az önmagunkkal kapcsolatos szeretetteljes figyelem és törődés megvalósítására utal. A tökéletesség ideájának elengedése, saját nehézségeink nagyobb távlatból szemlélése (pl. annak felismerése, hogy a mi élethelyzetünk bárkivel előfordulhat), illetve a jelen tudatosítása és hangsúlyozása az a három alappillér, amelynek begyakorlásával, szokássá alakításával megelózhetjük a negatív gondolati sémák, kognitív torzítások - mint például a katasztrofizálás - kialakulását, illetve mérsékelhetjük a meglévő, múködő negatív sémák hatását. A gyakorlat a redefiníció (a helyzet átkeretezése) kognitív technikája alkalmazásának példája is egyben. „Topdown" gyakorlat, egy nehéz helyzetben keletkező negatív gondolat, gondolati séma által kiváltott emóciók felismerését és átkeretezését indukálja.

A legegyszerúbb ilyen típusú gyakorlat 3 lépése a következő (Neff, 2014):

1. gondolat: Ez a helyzet szenvedést okoz nekem.

2. gondolat: A szenvedés az élet része. Nem csak az én tapasztalatom.

3. gondolat: Együttérzek magammal, kedves vagyok önmagamhoz, mert most erre van szükségem.

a) Egy kedves ismerős elképzelése: hogyan viselkedne velem (mosoly, érintés, $s t b$.)?

b) Egy barát elképzelése hasonló helyzetben: hogyan tudnék vele együttérző és kedves lenni?

Hasonló elgondoláson alapulnak az ún. együttérzésfókuszú terápiák is (Gilbert, 2009). Itt a cél a kliens szenzitivitásának csökkentése a distressz állapotokra, az empátia növelése, az érzelmek tartalmazási képességének fokozása az önmagával és a másokkal való együttérzés képességének támogatása révén, különböző helyzetgyakorlatok és technikák segítségével. Egyfajta „tréning”, amelynek során megtanulható a „biztonsági szisztéma” múködtetése, amely gátolni képes a félelemérzést/haragot és a kompenzatórikus ingerkeresést, azaz az inadekvát biztonsági stratégiákat. Például a figyelemfókusz átállítása a szelf pozitív aspektusaira, a környezet támogató, együttérző viselkedésére, a jó érzést okozó cselekedetekre, élményekre.

\subsubsection{Inspirációs napló irása}

Az együttérzésfókuszú megközelítés egyik gyakorlata - a sémaként múködő folyamatos önkritika, vagy mások/a világ kritikus szemléletének kiegyen- 
súlyozására javasolt technika - az „inspirációs napló” vezetése. Naponta 2-3 olyan élmény lejegyzése (írás, rajzolás, fotózás, stb.), ami jó érzéssel, érdeklődéssel tölti el a személyt. Ez egyrészt a figyelem fókuszát az itt és most megélésére, elsősorban a pozitív élményekre irányítja, másrészt motiváló hatású, támogatja a pozitív kapcsolódást mind önmagunkhoz, mind a környezetünkhöz. Ez különösen hasznos lehet internalizációs tüneteknél (pl. lehangoltság, reménytelenség érzése, depresszív állapotok), kiegyensúlyozza az alapvetóen negatív érzelmek és negatív gondolatok uralta alapállapotot. A saját gyakorlatomban tapasztaltak szerint 2-3 hónap naplóvezetés, amit a feljegyzett események közös átbeszélése követ, képes egy pozitívabb irányba fordítani a figyelmi fókuszt. ${ }^{7}$

\section{Megvitatás}

Krízishelyzetben, tartós stressz és traumák hatására az érzelmi szabályozás egyensúlya átmenetileg vagy tartósabban sérül. Klienseink azon túl, hogy nehezen tudják megfogalmazni - verbális szinten megjeleníteni - az átélt érzelmeket (arousalkontinuum-változásokat), gyakran tájékozatlanok azokat az eszközöket illetően is, amelyek segítségükre lehetnének az érzelemszabályozásban. A szakemberek, elsősorban a pszichológiai tanácsadás területén dolgozó pszichológusok számára a jelen tanulmány egy olyan szempontrendszert - az arousalváltozásokban bekövetkező fókuszt - javasol az érzelemszabályozási technikák, gyakorlatok alkalmazásához, ajánlásához, amely áttekinthetőbbé teszi a mit, mikor, hogyan kérdéseit.

A bemutatáskor törekedtem arra, hogy a módszerek, technikák és gyakorlatok hátterében álló idegrendszeri folyamatok, illetve érzelemszabályozással kapcsolatos funkciók átláthatóvá, érthetővé váljanak. Ahol lehetőség adódott rá, az alkalmazott módszerek hatásának kísérleti igazolásáról is beszámoltam.

A saját munkám során is alkalmazott technikák és gyakorlatok múködését két esetvignettával, a praxisomban készült alkotások bemutatásával, illetve tapasztalataim megosztásával törekedtem alátámasztani. A bemutatott gyakorlatok közel sem képviselik a teljes repertoárt, inkább csak ízelítőt adnak a különböző típusú regulációs nehézségek kezeléséhez elsősorban a tanácsadás szintjén, de bizonyos módszerek esetében (pl. múvészetterápiák) a pszichoterápiás alkalmazás lehetősége is bemutatásra került.

7 https://gallerypsziche.blog.hu/2018/03/04/inspiralodjunk 
A munka - eddigi tapasztalataim szerint - nemcsak inspiráló, hanem valódi segítséget is jelent klienseiknek az akut krízishelyzetekben és a hétköznapok megterhelő helyzeteiben hosszabb távon is, ugyanakkor krónikus traumatizáció esetén jó alapot nyújt a traumaterápia előkészítését szolgáló ún. stabilizációs fázisban.

\section{Irodalom}

Andrejkovics, M. (2015). A gyermekkori bántalmazás neurobiológiai vonatkozásai. In I. Kuritárné Szabó, \& E. Tisljár-Szabó (Szerk.), Úgy szerettem volna, ha nem bántottak volna (89-106). Budapest: Oriold és Társai Kiadó

Antalfai, M. (2007). Katarzis-élményre épülő tematikus múvészet-pszichoterápia. Gyógyítás és egészségfejlesztés önkifejezéssel. In Zs. Demetrovics, Gy. Kökönyei, \& A. Oláh (Szerk.), Személyiséglélektantól az egészségpszichológiáig. Tanulmányok Kulcsár Zsuzsanna tiszteletére (356-383). Budapest: Trefort Kiadó

Antalfai, M. (2016). Alkotás és kibontakozás. A Katarzisz Komplex Müvészetterápia elmélete és gyakorlata. Budapest: Lélekben Otthon Közhasznú Alapítvány

Badenoch, B. (2008). Being a brain-wise therapist: A practical guide to interpersonal neurobiology. New York: W. W. Norton \& Co.

Bagdy, E., \& Koronkai, B. (1988). Relaxációs módszerek. Budapest: Medicina

Bakó, T. (1992). Titkok nélkül. Lélektani vizsgálódások az öngyilkosságról. Budapest: Cserépfalvi

Bakó, T. (1996). Verem mélyén - Könyv a krízisről. Budapest: Cserépfalvi

Balikó, M. (1990). Tele/pszicho/fon. (Öngyilkosság-megelőzés lehetöségei telefonon át). Budapest: Animula

Bartels, A., \& Zeki, S. (2004). The neural correlates of maternal and romantic love. Neurolmage, 21, 1155- 1166.

Bauer, I.M., \& Baumeister, R.F. (2011). Self-regulatory strength. In K.D. Vohs, \& R.F. Baumeister (Eds.), Handbook of self-regulation. Research, theory, and applications $2^{\text {nd }}$ edition (64-82). New York, London: The Guilford Press

Bolwerk, A., Mack-Andrick, J., Lang, F.R., Dörfler, A., \& Maihöfner, C. (2014). How art changes your brain: differential effects of visual art production and cognitive art evaluation on functional brain connectivity. Plos One, 9(7), e101035. Doi: 10.1371/journal. pone.0101035

Bóna, A., Kun, B., Kökönyei, Gy., \& Demetrovics, Zs. (2013). Az affektív szabályozás zavarai és következményei. Evészavarok és addiktív betegségek. Magyar Pszichológiai Szemle, 68(1), 71-88.

Boon, S., Steele, K., \& Van der Hart, O. (2011). Coping with trauma-related dissociation. Skills training for patients and their therapists. New York, London: W. W. Norton \& Company

Brain Gym Studies. Letöltve: 2018. 01.12-én: http://www.braingym.org/studies

Brain gym: Simple brain gym exercises to awaken the brain for learning readiness, Integrated Learning Strategies. Letöltve: 2018. 01.12-én: https://ilslearningcorner.com/2017-01brain-gym-simple-brain-gym-exercises-to-awaken-the-brain-for-learning-readiness /

Brown, K. (2012). Educate your brain. Use mind-body balance to learn faster, work smarter and move more easily through life. Phoenix, Arizona: Balance Point Publishing LLC

Caplan, G. (1964). Principles of preventive psychiatry. New York: Basic Book 
Cicchetti, D., Rogosch, F.A., \& Toth, S.L. (1998). Maternal depressive disorder and contextual risk: Contributions to the development of attachment insecurity and behavior problems in toddlerhood. Development and Psychopathology, 10(2), 283-300.

Cloitre, M., Garvert, D.W., Brewin, C.R., Bryant, R.A., \& Maercker, A. (2013). Evidence for proposed ICD-11 PTSD and complex PTSD: a latent profile analysis. European Journal of Psychotraumatology, 4(1), 20706. Doi: 10.3402/ ejpt.v4i0.20706

Clow, A., \& Freidhoi, C. (2006). Normalisation of salivary cortisol levels and self-report stress by a brief lunchtime visit to an art gallery by London City workers. Journal of Holistic Healthcare, 3(2), 28-32.

Corrigan, F.M., Fisher, J.J., \& Nutt, D.J. (2011). Autonomic dysregulation and the window of tolerance model of the effects of complex emotional trauma. Journal of Psychopharmacology, 25(1), 17-25.

Crittenden, P.M. (2000). A dynamic-maturational approach to continuity and change in pattern of attachment. In P.M. Crittenden, \& A.H. Claussen, (Eds.), The organization of attachment relationships - Maturation, culture, and context. Cambridge: Cambridge University Press

Csabai, M., \& Pintér, J.N. (2013). Pszichológia a gyógyitásban. Budapest: Oriold és Társai Kiadó

Csürke, J., Vörös, V., Osváth, P., \& Árkovits, A. (2014) (Szerk.), Mindennapi kríziseink. A lélektani krízis és a krízisintervenció kézikönyve. Budapest: Oriold és Társai Kiadó

Dahlitz, M.J. (2015). Neuropsychotherapy: Defining the emerging paradigm of neurobiologically informed psychotherapy. International Journal of Neuropsychotherapy, 3(1), 47-69.

Davidson, R.J., Kabat-Zinn, J., Schumacher, J., Rosenkranz, M.A., Muller, D., Santorelli, S.F., et al. (2003). Alterations in brain and immune function produced by mindfulness meditation. Psychosomatic Medicine, 65, 564-570.

Del Río-Casanova, L., González, A., Páramo, M., Van Dijke, A., \& Brenlla, J. (2016). Emotion regulation strategies in trauma-related disorders: pathways linking neurobiology and clinical manifestations. Reviews in the Neurosciences, 27(4), 385-395.

Dennison, P.E., \& Dennison, G.E. (2010). Brain gym. Teacher's edition. Letöltve: 2018. 02. 20án: https://www.braingym.com/product/brain-gym-teachers-edition/

Dennison, P. E., \& Dennison, G. E. (2017). Brain Gym: 101-Balance for Daily Life. Letöltve 2018. 02. 20-án: https://www.braingym.com/product/brain-gym-101-balance-for-dailylife/

Diamond, S.J. (2001). Educational Kinesiology, movement, and sensory integration: A review of recent, relevant, neuroscientific literature, Brain Gym Journal, 15(1-2), 4, 21.

DSM-5 (2014). DSM-5 referencia kézikönyv a DSM-5 diagnosztikai kritériumaihoz. American Psychiatric Association. Budapest: Oriold és Társai Kft.

Eiden R.D., Edwards E.P., \& Leonard, K.E. (2007). A conceptual model for the development of externalizing behavior problems among kindergarten children of alcoholic families: role of parenting and children's self-regulation. Developmental Psychology, 7(43), 11871201.

Eisenberg, N., Spinrad, T.L., \& Eggum, N.D. (2010). Emotion-related self-regulation and its relation to children's maladjustment. Annual Review Clinical Psychology, 27(6), 495-525.

Fox, N., \& Calkins, S.D. (2003). The development of self-control of emotion: Intrinsic and extrinsic influences. Motivation and Emotion, 27(1), 7-26.

Fülöp, E. (2013). Másodlagos traumatizáció és kiégés összefüggései az érzelemszabályozási folyamatokkal, In M. Csabai, \& J. Pintér (Szerk.), Pszichológia a gyógyításban (167-191). Budapest: Oriold és Társai Kiadó 
Gardiner, T., Jaspers, M., \& Jaastad, L. (2014). The Ronnie Gardiner Method - reconnecting body and mind through music and rhythm.14 ${ }^{\text {th }}$ World Congress of Music Therapy. Vienna, Austria, July 7-12, 2014. Letöltve: 2018. 08. 24-én: http:/ / www.musictherapy2014. org/fileadmin/download/Abstract_Book_WCMT_2014_01.pdf

Gáti, Á. (2002). Pszichotraumák patogenetikai és terápiás vonatkozásai. PhD értekezés. Pécsi Tudományegyetem, Pécs

Gilbert, P. (2009). Introducing Compasson-focused Therapy. Advances in Psychiatric Treatment, 15(3), 199-208.

Gladding, S.T., \& Newsome, D.W. (2003). Art in counseling. In C.A. Malchiody (Ed.), Handbook of art therapy (243-253). New York: The Guilford Press

Goldberg, S.B., Wampold, B., Tucker, R., Davidson, R.J., Simpson, T., Kearney, D., et al. (2018). Mindfulness-based interventions for psychiatric disorders: A systematic review and meta-analysis. Clinical Psychology Review, 59(2018), 52-60.

Goldsmith, H.H., Pollak, S.D., \& Davidson, R.J. (2008). Developmental neuroscience perspectives on emotion regulation. Child Development Perspectives, 2(3), 132-140.

Gonzalez, A. (2016). Emotion dysregulation in psychoform and somatoform dissociation: From neurobiology to clinical interventions with EMDR. Presentation at the at the 17th. EMDR Europe Association Conference, The Hague. Letöltve: 2016. 07. 30-án: https:/ / emdria.omeka.net/items/show/23898

Gonzalez, A., \& Mosquera, D. (2012). EMDR and dissociation. The progressive approach. AI.

Grandin, T. (1992). Calming effects of deep touch pressure in patients with autistic disorder, college students, and animals. Journal of Child and Adolescent Psychopharmacology, 2(1), 63-72.

Greenberg, L.S. (2008). The clinical application of emotion in psychotherapy. In M. Lewis, J.M. Haviland-Jones, \& L.F. Barrett (Eds.), Handbook of Emotions (88-102). New YorkLondon: The Guilford Press

Gross, J.J. (1998). The emerging field of emotion regulation: An integrative review. Review of General Psychology, 2, 271-299.

Gross, J.J., \& John, O.P. (1997). Revealing feelings: Facets of emotional expressivity in selfreports, peer ratings, and behavior. Journal of Personality and Social Psychology, 72, 435-448.

Grossman, P., Niemann, L., Schmidt, S., \& Walach, H., (2007). Mindfulness-based stress reduction and health benefits. A meta-analysis. Explore, 3(6), 585-591.

Harmatiné Olajos, T., \& Pataky, N. (2014). A lelki egészség személyiségdinamikai kettősségei - kihívások a tehetséggondozásban. Géniusz Mühely, 10, 3-21.

Heim, C., \& Nemeroff, C.B., (2001). The role of childhood trauma in the neurobiology of mood and anxiety disorders. Preclinical and clinical studies. Society of Biological Psyciatry, 49, 1023-1039.

Herbert, A. \& Esparham, A. (2017). Mind-Body Therapy for Children with Attention-Deficit/ Hyperactivity Disorder. Children, 4(5), 1-13.

Holmes, T.H., \& Rahe, R.H. (1967). The social reajustment scale. Journal of Psychosomatic Research, 11, 213-218.

Hull, M.A. (2002). Neuroimaging findings in post-traumatic stress disorder: Systematic review. The British Journal of Psychiatry, 181(2), 102-110.

Integrated Learning Strategies (2017). Brain Gym: Simple brain gym exercises to awaken the brain for learning readyness. Letöltve: 2018. 01.12-én: https://ilslearningcorner.com/201701-brain-gym-simple-brain-gym-exercises-to-awaken-the-brain-for-learning-readiness /

Ivens, S. (2018). Erdőterápia. Budapest: Libri Kiadó

Janet, P. (1919). Les medications psychologiques (Vol. 3). Paris: Félix Alcan. (Reprint: Paris: Société Pierre Janet, 1984). English edition: Principles of Psychotherapy (2). New York: Macmillan. (Reprint: New York: Arno Press, 1976). 
Kalmanowitz, D., \& Ho, R.T. (2016). Out of our mind. Art therapy and mindfulness with refugees, political violence and trauma. The Arts in Psychotherapy, 49, 57-65.

Kiss, E., \& Sz. Makó, H. (2015). (Szerk.), A gyász, krízis, trauma és a megküzdés lélektana. Pécs: Pro Pannonia Kiadó

Koelman, A. (1997). Movement or medication? The alleviation of ADD. Brain Gym Journal, 11(3), 5.

Kral, T.R.A., Schuyler, B.S., Mumford, J.A., Rosenkranz, M.A., Lutz, A., \& Davidson, R.J. (2018). Impact of short- and long-term mindfulness meditation training on amygdala reactivity to emotional stimuli. NeuroImage, 181, 301-313.

Kulcsár, Zs. (1993). Pszichoszomatika. Budapest: Nemzeti Tankönyvkiadó

Kulcsár, Zs. (2005). A társas interakciók pszichológiai hatásai és agyi mechanizmusai. Egy hipotézis körvonalai. Társas támogatás. In Zs. Kulcsár (Szerk.), Teher alatt... Pozitív traumafeldolgozás és poszttraumás személyiségfejlődés (315-393). Budapest: Trefort Kiadó

Kulcsár, Zs. (2009). Traumafeldolgozás és vallás, Budapest: Trefort Kiadó

Kuritárné Szabó, I., \& Tisljár-Szabó, E. (2015). (Szerk.), Úgy szerettem volna, ha nem bántottak volna, Budapest: Oriold és Társai Kiadó

Láng, A. (2009). Érzelemszabályozás és kötődés összefüggései normatív mintában. Alkalmazott Pszichológia, 11(3-4), 5-17.

Láng, A. (2015). A traumatikus életesemények pszichoterápiás szempontjai. In E. Kiss, \& H. Sz. Makó (Szerk.), A gyász, krízis, trauma és a megküzdés lélektana (235-248). Pécs: Pro Pannonia Kiadó

Láng, A., \& Nagy, L. (2013). Kötődéselmélet és fejlődési pszichopatológia - szemlélet, modellek, közvetítő mechanizmusok. Magyar Pszichológiai Szemle, 68(1), 23-37.

Lanius, R.A., Vermetten, E., Loewenstein, R.J., Brand, B., Schmahl, C., Bremner, J.D., et al. (2010). Emotion modulation in PTSD: Clinical and neurobiological evidence for a dissociative subtype. American Journal of Psychiatry, 167(6), 640-647.

Li, Q. (2010). Effect of forest bathing trips on human immune function. Environmental Health and Preventive Medicine, 15(1), 9-17.

Macklem, G.L. (2008). Practitioner's guide to emotion regulation in school aged children. Berlin: Springer Science \& Business Media

Nagy, I. (2016). Sürgősségi helyzetek lélektani vonatkozásai és az alkalmazható pszichológiai eszközök. Előadás a Magyar Oxiológiai Társaság XVIII. Vándorgyúlésén, Szeged, 2016. 04. 15-16. Letöltve: 2018. 02. 23-án: https:/ / prezi.com/cf1evhempofq/ surgossegihelyzetek-lelektani-vonatkozasai-es-az-alkalmazha/

Neff, K. (2014). Együttérzés önmagunkkal. Budapest: Ursus Libris Kiadó

Neff, K., \& Davidson, O. (2016). Self-compassion: Embracing suffering with kindness. In I. Ivtzan, \& T. Lomas (Eds.), Mindfulness in positive psychology (37-50). London: Rutledge

Ogden, P., \& Minton, K. (2000). Sensorimotor Psychotherapy: One method for processing traumatic memory. Traumatology, 6(3), Article 3.

Ogden, P., Pain, C., \& Fischer, J. (2006). A sensorimotor approach to the treatment of trauma and dissociation. Psychiatric Clinics of North America, 29, 263-279.

Oláh, A. (2005). Érzelmek, megküzdés és optimális élmény. Belső világunk megismerésének módszerei. Budapest: Trefort Kiadó

Ostacoli, L., \& Bertino, G. (2015). Free the hidden heart: resources and attachment work in resistent depression. Elhangzott: 16. EMDR Europe Conference, Milano, 2015. 07. 10-12.

Perry, B.D. (2004). Understanding traumatized and maltreated children: The core concepts, TRAIN-THE-TRAINER SERIES materials developed by the ChildTrauma Academy. Letöltve: 2016. 05. 14-én: http:/ / childtrauma.org/ és https:/ / trove.nla.gov.au/work/ 33733875 ?q\&versionId $=41490870$ 
Perry, B.D. (2009). Examining child maltreatment through a neurodevelopmental lens: Clinical applications of the neurosequential model of therapeutics. Journal of Loss and Trauma, 14, 240-255.

Perry, B.D., \& Dobson, C L. (2014). The neurosequential model of therapeutics, In C.A. Courtois, \& J.D. Ford (Eds.), Treating complex traumatic stress disorders in children and adolescents (249-260). New York, London: The Guilford Press

Pohárnok, M., \& Lénárd, K. (2015). A trauma lélektana. In E. Kiss, \& H. Sz. Makó (Szerk.), A gyász, krízis, trauma és a megküzdés lélektana (221-235). Pécs: Pro Pannonia Kiadó

Pohl, P., Dizdar, N., \& Hallert, E. (2013). The Ronnie Gardiner rhythm and music method - a feasibility study in Parkinson's disease, Disability and Rehabilitation, 35(26), 2197-2204.

Porges, S.W. (2007). The polyvagal perspective. Biological Psychology, 74(2), 116-143.

Porges, S.W. (2009). The polyvagal theory: New insights into adaptive reactions of the autonomic nervous system. Cleveland Clinical Journal of Medicine, 76(S2), 86-90.

Roberts, A.R. (2002). Assessment, crisis intervention, and trauma treatment: The integrative ACT intervention model. Brief Treatment and Crisis Intervention, 2(1), 1-22.

Roberts, A.R., \& Ottens, A.J. (2005). The seven-stage crisis intervention model: A road map to goal attainment, problem solving, and crisis resolution. Brief Treatment and Crisis Intervention, 5(4), 329-339.

Rossi, E. (1986). The psychobiology of mind-body healing. New York: Norton

Rossouw, P.J. (2014). Neuropsychotherapy: Theoretical underpinnings and clinical applications. Brisbane, Qld: Mediros Pty Ltd.

Rothbart, M.K., \& Putnam, S.P. (2002). Temperament and socialization. In L. Pulkkinen, \& A. Caspi, (Eds.), Personality in the Life Course: Paths to Successful Development (19-45). New York, NY, US: Cambridge University Press

S. Nagy, Z. (2009). Polivagális elmélet, új perspektíva a pszichofiziológiában: a vegetatív idegrendszer mint szociális idegrendszer. Alkalmazott Pszichológia, 11(3-4), 77-102.

Schore, A.N. (2012). The science of the art of psychotherapy. New York, NY: W.W. Norton \& Co.

Schore, A.N. (2014). The right brain is dominant in psychotherapy. Psychotherapy, 51(3), 388-397.

Schütz, M. (2002). Can the Ronnie Gardiner method improve language, communication and quality of life with aphasia? Master's thesis in speech and language pathology. University of Gothenburg, Gothenburg

Selye, J. (1964). Életünk és a stressz. Budapest: Akadémia kiadó

Shapiro, F. (2016). Gyözd le a múltad! Vedd kezedbe az életed az EMDR-terápia módszerével. Budapest: Medicina Kiadó

Siegel, D. (1999). The developing mind. New York: The Guilford Press

Spinrad, T.L., Eisenberg, N., Gaertner, B., Popp, T., Smith, C.L., Kupfer, A., et al. (2007). Relations of maternal socialization and toddlers' effortful control to children's adjustment and social competence. Developmental Psychology, 43, 1170-1186.

Stevens, J.S., Kim, Y.J., Galatzer-Levy, I.R., Reddy, R., Ely, T.D., Nemeroff, C.B., et al. (2017). Amygdala reactivity and anterior cingulate habituation predict posttraumatic stress disorder symptom maintenance after acute civilian trauma, Biological Psychiatry, 81(12), 1023-1029.

Telkes, J. (1989). Válság, változás, változtatás. A kríziskoncepció jelentősége a mentálhigiénés gyakorlatban. In J. Gerevich (Szerk.), Közösségi mentálhigiéné (101-112). Budapest: Gondolat Kiadó

Thompson, R.A. (1994). Emotion regulation: A theme in search of definition. Monographs of the Society for Research in Child Development, 59(240), 25-52. 
Van der Hart, O. (2012). The use of imagery in phase 1 treatment of clients with complex dissociative disorders. European Journal of Psychotraumatology, 3: 8458. Doi: 10.3402/ ejpt. v3i0.8458

Van der Hart, O., Brown, P., \& Van der Kolk, B.A. (1989). Pierre Janet's treatment of posttraumatic stress. Journal of Traumatic Stress, 2(4), 379-395.

Van der Kolk, B.A. (2011). Developmental trauma disorder: Towards a rational diagnosis for children with complex trauma histories. In R.A. Lanius, E. Vermetten, \& C. Pain, (Eds.), The impact of early life trauma on health and desease (57-68). Cambridge: Cambridge University Press

Van der Kolk, B. A., Pelcovitz, D., Roth, S., Mandel, F. S., McFarlane, A., \& Herman, J. L. (1996). Dissociation, somatization, and affect dysregulation: the complexity of adaptation of trauma. The American Journal of Psychiatry, 153(7), 83-93.

Van der Kolk, B.A., Roth, S.,Pelcovitz, D., Sunday, S., \& Spinazzola J. (2005). Disorders of extreme stress: The empirical foundation of a complex adaptation to trauma. Journal of Traumatic Stress, 18(5), 389-399.

Vas, J.P. (2007). A kétszemélyes pszichoterápia hatótényezői: egy interaktív neuropszichológiai értelmezés vázlata. Psychiatria Hungarica,21(5), 332-350.

Wilson, K.R., Hansen, J.H., \& Li, M. (2011). The traumatic stress response in child maltreatment and resultant neuropsychological effects. Aggression and Violent Behaviour, 16(2), 87-97.

Yates, T.M., Dodds, M.F., Sroufe, L.A., \& Egeland, B. (2003). Exposure to partner violence and child behavior problems: A prospective study controlling for child physical abuse and neglect, child cognitive ability, socioeconomic status, and life stress. Development and Psychopathology, 15, 199-218.

Zeidan, F., Emerson, N.M., Farris, S.R., Ray, J.N., Jung, Y., McHaffie, J.G., et al. (2015). Mindfulness meditation-based pain relief employs different neural mechanisms than placebo and sham mindfulness meditation-induced analgesia. Journal of Neuroscience, 35(46), 15307-15325.

Zeidan, F., Johnson, S.K., Diamond, B.J., David, Z., \& Goolkasian, P. (2010). Mindfulness meditation improves cognition: Evidence of brief mental training. Consciousness and Cognition, 19(2), 597-605.

Zelano, C., Jiang, H., Zhou, G., Arora, N., Schuele, S., Rosenow, J., et al. (2016). Nasal respiration entrains human limbic oscillations and modulates cognitive function. Journal of Neuroscience, 36(49), 12448-12467.

Zentainé Kriszt, R. (1997). Nyári napközis táborok - másképpen. Új Pedagógiai Szemle, 47(9), 79-84.

\section{Nyilatkozat érdekütközésról}

A szerző kijelenti, hogy esetében nem állnak fenn érdekütközések. 


\title{
Changes of emotion regulation in crisis and trauma - useful techniques and practices in counselling that support restoration
}

\author{
MOGYORÓSY-RÉVÉSZ, ZSUZSANNA
}

This study is focusing on emotion regulation, one of the basic processes of self-regulation. The review of some of the concepts of emotion regulation and its basic neurophysiological mechanisms is followed by the presentation of the acute and chronic stress effects and the related adaptive physiological responses, with special respect to the changes in the arousal processes. Although it has a crucial importance, the relation between the activation level modifications as a result of chronic stress and the attachment attributes as well as the subsequent psychopathology is only outlined. The most important aim of this paper is the systematic review of techniques and practices - applicable also in counselling - which can assist clients to restore their self-regulation processes. The review, that follows the categorization (hyper- and hypo-arousal) developed based on the changes identified in the arousal continuum provides some guidance on how to support clients in the development of a more adequate stress management and emotion regulation strategy along with a habit system, constituting to a tailor made "self-care plan". The starting point of the "counselling focus" supporting emotion regulation is the analysis of the stress management strategies, followed by an education and training process, during which the client is able to acquire and turn into habits the emotion regulation techniques and practices that fit the most to her/his actual state of mind. In addition to the summary of practical experiences, our results are illustrated by two case vignettes as well.

Keywords: emotion regulation, arousal, hyper-activation, hypo-activation, stress, crisis, emotion regulation techniques

A cikk a Creative Commons Attribution 4.0 International License (https:/ / creativecommons.org/ licenses/by/4.0/) feltételei szerint publikált Open Access közlemény, melynek szellemében a cikk bármilyen médiumban szabadon felhasználható, megosztható és újraközölhető, feltéve, hogy az eredeti szerzó és a közlés helye, illetve a CC License linkje és az esetlegesen végrehajtott módosítások feltüntetésre kerülnek. (SID_1) 